\title{
Biochemical pathways for the production of flavour compounds in cheeses during ripening: A review
}

\author{
Paul L.H. McSweEneY*, Maria José SousA \\ Department of Food Science and Technology, University College, Cork, Ireland
}

(Received 5 February 1999; accepted 4 October 1999)

\begin{abstract}
The principal pathways for the formation of flavour compounds in cheese (glycolysis, lipolysis and proteolysis) are reviewed. Depending on variety, microflora and ripening conditions, lactate may be metabolized by a number of pathways to various compounds which contribute to cheese flavour or off-flavours. Citrate metabolism by citrate-positive lactococci or Leuconostoc spp. is important in certain varieties (e.g., Dutch cheeses). Lipolysis results directly in the formation of flavour compounds by liberating free fatty acids (FFA). FFA may also be metabolized to alkan-2-ones and fatty acid lactones. Proteolysis of the caseins to a range of small- and intermediate-sized peptides and free amino acids (FAA) probably only contributes to the background flavour of most cheese varieties, but FAA are important precursors for a range of poorly-understood catabolic reactions which produce volatile compounds essential for flavour.
\end{abstract}

cheese / flavour / volatile flavour compound

Résumé - Principales voies métaboliques conduisant à la production de composés aromatiques au cours de l'affinage (revue). Cet article passe en revue les principales voies métaboliques (glycolyse, lipolyse, protéolyse) conduisant à la formation de composés d'arômes dans les fromages. Selon les types de fromage considérés, la microflore et les conditions d'affinage, le lactate peut être transformé en de nombreux métabolites contribuant aux arômes du fromage ou produisant des défauts de flaveur. Le métabolisme du citrate réalisé par les espèces de lactocoques citrate-positives ou par Leuconostoc ssp. est d'une grande importance dans certains fromages, notamment de type Gouda. La lipolyse conduit directement à la formation de composés d'arômes résultant de la libération d'acides gras. Les acides gras libres peuvent également être transformés en alcan-2-ones et lactones. La protéolyse des caséines en peptides de différentes tailles (courts et intermédiaires) et en acides aminés libres ne contribue probablement qu'à la production d'arômes communs à la plupart des fromages, mais les acides aminés libres sont d'importants précurseurs d'une grande variété de réactions cataboliques encore mal élucidées, qui produisent des composés volatils essentiels pour la flaveur.

fromage / arôme / composé volatil

* Correspondence and reprints

Tel.: 353219020 11; fax: 353212700 01; e-mail: pmcs@ucc.ie

Oral communication at the Symposium on Quality and Microbiology of Traditional and Raw Milk Cheeses of the Cost 95 Meeting, Dijon, France, 30 Nov.-1 Dec., 1998. 


\section{INTRODUCTION}

"There is a cheese for every taste-preference and a taste-preference for every cheese" [109]. Unlike many processed food products for which stability is the key criterion, cheese is a biochemically dynamic product and undergoes significant changes during its ripening period. Freshly-made curds of various cheese varieties have bland, and largely similar, flavours and it is during the ripening period that flavour compounds are produced which are characteristic of each variety. Originally it was thought that cheese flavour resulted from a single compound or class of compounds. While this is largely true for blue-mould varieties (whose flavour is dominated by alkan-2ones), it is now generally accepted that the flavour of most cheeses results from the combination of a large number of sapid compounds present in the correct ratios and concentrations ('component balance theory' $[15,71,97])$. Hundreds of compounds have been implicated in cheese flavour; some of which have been identified in Cheddar cheese and are listed in Table I. The major biochemical pathways which occur in cheese ripening are the following: the metabolism of residual lactose, lactate and citrate (sometimes, although erroneously, referred to as 'glycolysis'), liberation of free fatty acids, FFA (lipolysis), associated catabolic reactions and the degradation of the casein matrix to a range of peptides and free amino acids, FAA (proteolysis), and subsequent reactions involved in the catabolism of FAA (Fig. 1).

There has been extensive research in recent decades into cheese flavour and the agents responsible for the production of sapid compounds. However, only limited information is available on the flavour

Table I. Some flavour compounds which have been identified in Cheddar cheese (adapted from Urbach [138]).

Tableau I. Composés aromatiques identifiés dans le fromage Cheddar (d'après Urbach [138]).

\begin{tabular}{lll}
\hline acealdehyde & dimethyl disulphide & 3-methylbutanol \\
acetoin & dimethyl trisulphide & 3-methyl-2-butanone \\
acetone & $\delta$-dodecalactone & 3-methylbutyric acid \\
acetophenone & ethanol & 2-nonanone \\
$\beta$-angelicalatone & ethyl acetate & S-octalactone \\
1, 2-butanediol & 2-ethyl butanol & n-octanoic acid \\
n-butanol & ethyl butyrate & 2-octanol \\
2-butanol & ethyl hexanoate & 2, 4-pentanediol \\
butanone & 2-heptanone & n-pentanoic acid \\
n-butyl acetate & n-hexanal & 2-pentanol \\
2-butyl acetate & n-hexanoic acid & pentan-2-one \\
n-butyl butyrate & n-hexanol & n-propanol \\
n-butyric acid & 2-hexanone & propanal \\
carbon dioxide & hexanethiol & propenal \\
$p$-cresol & 2-hexenal & n-propyl butyrate \\
$\gamma$-decalactone & isobutanol & tetrahydrofuran \\
$\delta$-decalactone & isohexanal & thiophen-2-aldehyde \\
n-decanoic acid & methane thiol & 2-tridecanone \\
diacetyl & methional & 2-undecanone \\
diethyl ether & 2-methyl acetate & \\
dimethyl sulphide & & \\
\hline
\end{tabular}


(a)

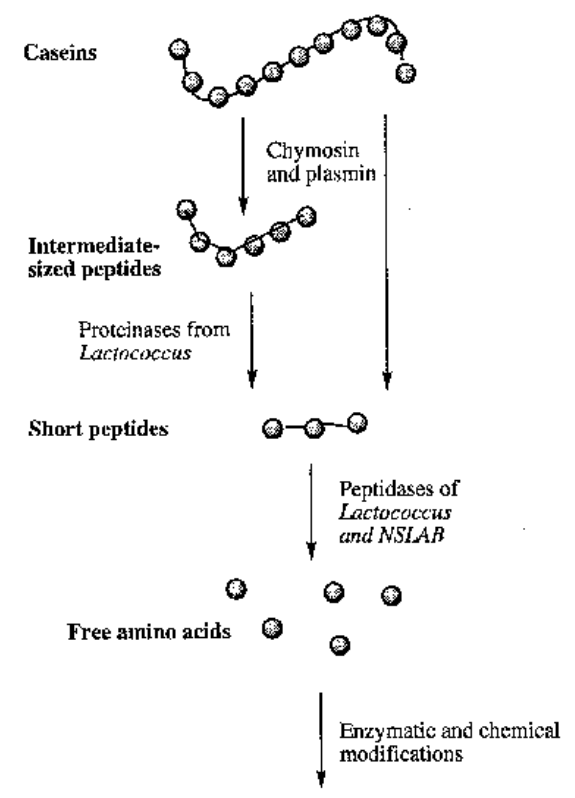

Volatile flavour compnunds (b)

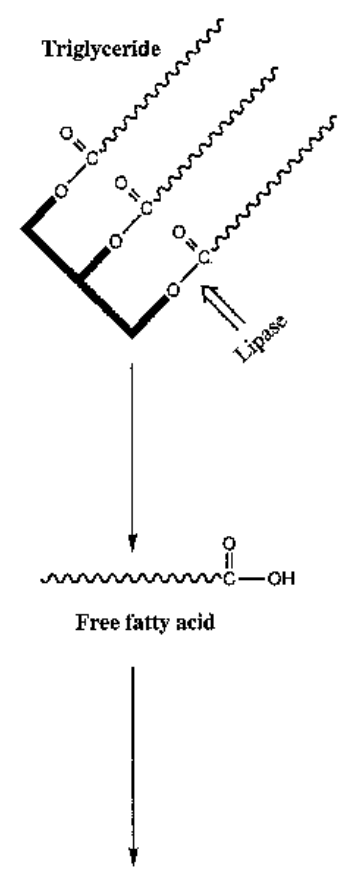

Yolatile flawaur compounds (c)
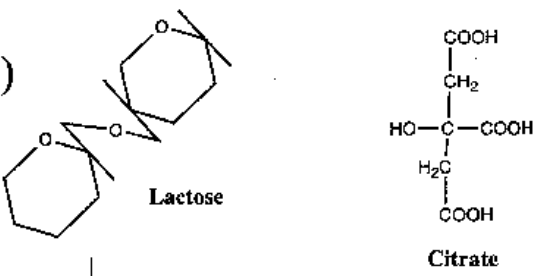

Citrate

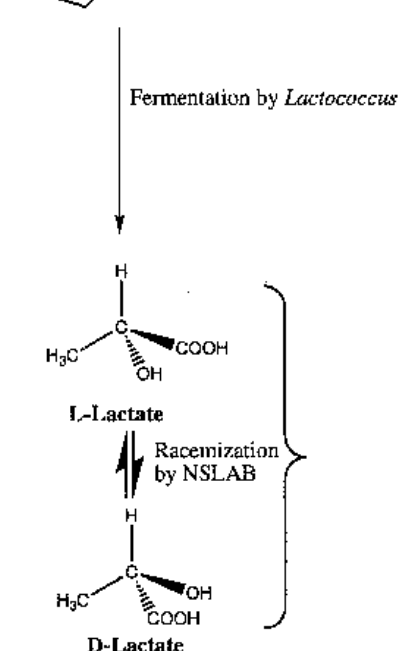

D-Lactate

Figure 1. General pathways for the biochemistry of cheese ripening: (a) proteolysis, (b) lipolysis, and (c) metabolism of lactose, lactate and citrate. Figure 1. Principaux mécanismes biochimiques de l'affinage : (a) protéolyse, (b) lipolyse et (c) métabolisme du lactose, du lactate et du citrate. 


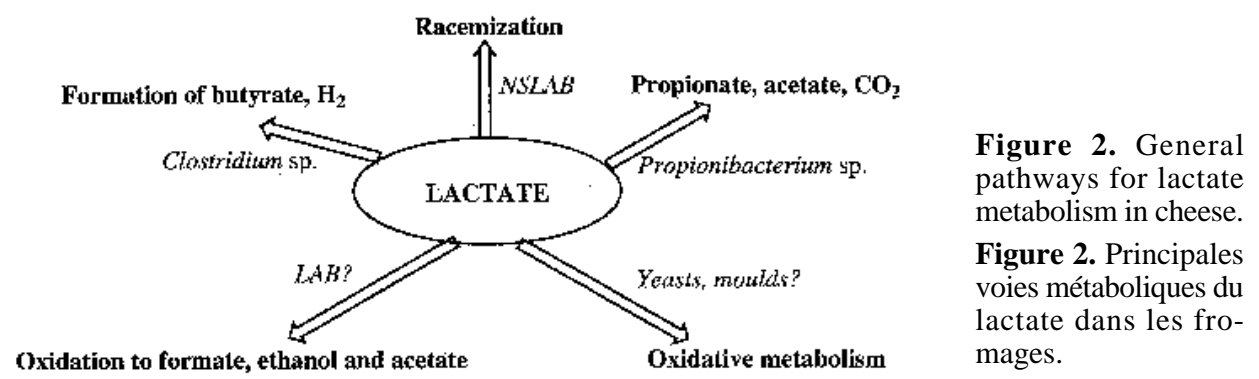

chemistry of many varieties, and it is impossible to accurately reproduce the flavour of any cheese by a mixture of pure compounds.

The objectives of this review are not to discuss the relative importance of specific volatile compounds to the perception of flavour in various cheese varieties, but rather to summarize the principal biochemical pathways by which flavour compounds are produced. Cheese flavour has been the subject of a number of reviews $[2,50,53,78$, 93, 95, 96, 109, 129, 138].

\subsection{Metabolism of lactose, lactate and citrate}

The metabolism of lactose to lactate is essential to the production of all cheese varieties. Depending on starter type, lactose is metabolized by the glycolytic (most starter bacteria) or phosphoketolase (Leuconostoc spp.) pathways (see [26]). The principal products of lactose metabolism are L- or D-lactate or a racemic mixture of both, although some strains, e.g., Leuconostoc spp., produce other products, e.g., ethanol [140]. Certain starter bacteria (e.g., Streptococcus thermophilus) are unable to metabolize the galactose moiety of lactose and must grow with galactose-positive $\left(\mathrm{Gal}^{+}\right)$ microorganisms (e.g., $\mathrm{Gal}^{+}$lactobacilli), or galactose will accumulate in the curd. Lactate contributes to the flavour of acid-curd cheeses and probably also contributes to the flavour of ripened cheese varieties, particu- larly early in maturation. Acidification of the cheese has a major indirect effect on flavour, since it determines the buffering capacity of the cheese and thus the growth of various microorganisms during ripening and the activity of the enzymes involved in cheese ripening. Depending on variety, lactate may also be further metabolized by a number of pathways to various compounds which contribute to cheese flavour (Fig. 2).

The non-starter microflora of Cheddar, Dutch-type and similar cheeses isomerize the L-lactate produced by the Lactococcus starter to D-lactate (see Scheme 1) [136]. The production of D-lactate during ripening is probably greater in cheeses made from raw milk but, as far as we are aware, only few studies have investigated this [130, 131]. Racemization of lactate has little impact on flavour but may have undesirable nutritional consequences, particularly for infants. The solubility of Ca-D-lactate is less that that of Ca-L-lactate, and Ca-D-lactate may crystallize in cheese forming white specks, particularly on cut surfaces (see [51]).

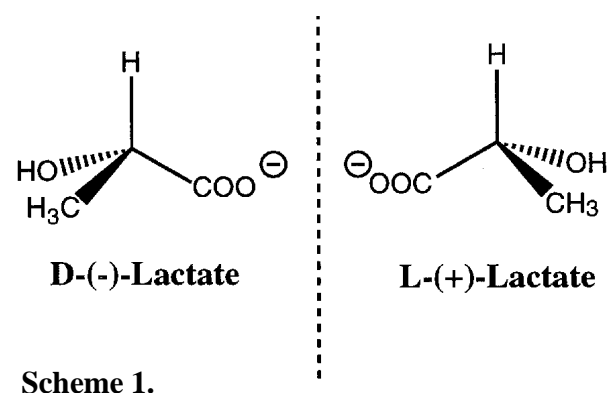


Lactate can be oxidized in vitro to acetate and $\mathrm{CO}_{2}$ by components of the non-starter lactic acid bacteria (NSLAB) present in hard cheeses ([53]; Fig. 3). The size of the cheese and oxygen permeability of the rind or packaging material influence the availability of $\mathrm{O}_{2}$ in the cheese. However, it is unlikely that this pathway occurs to a significant

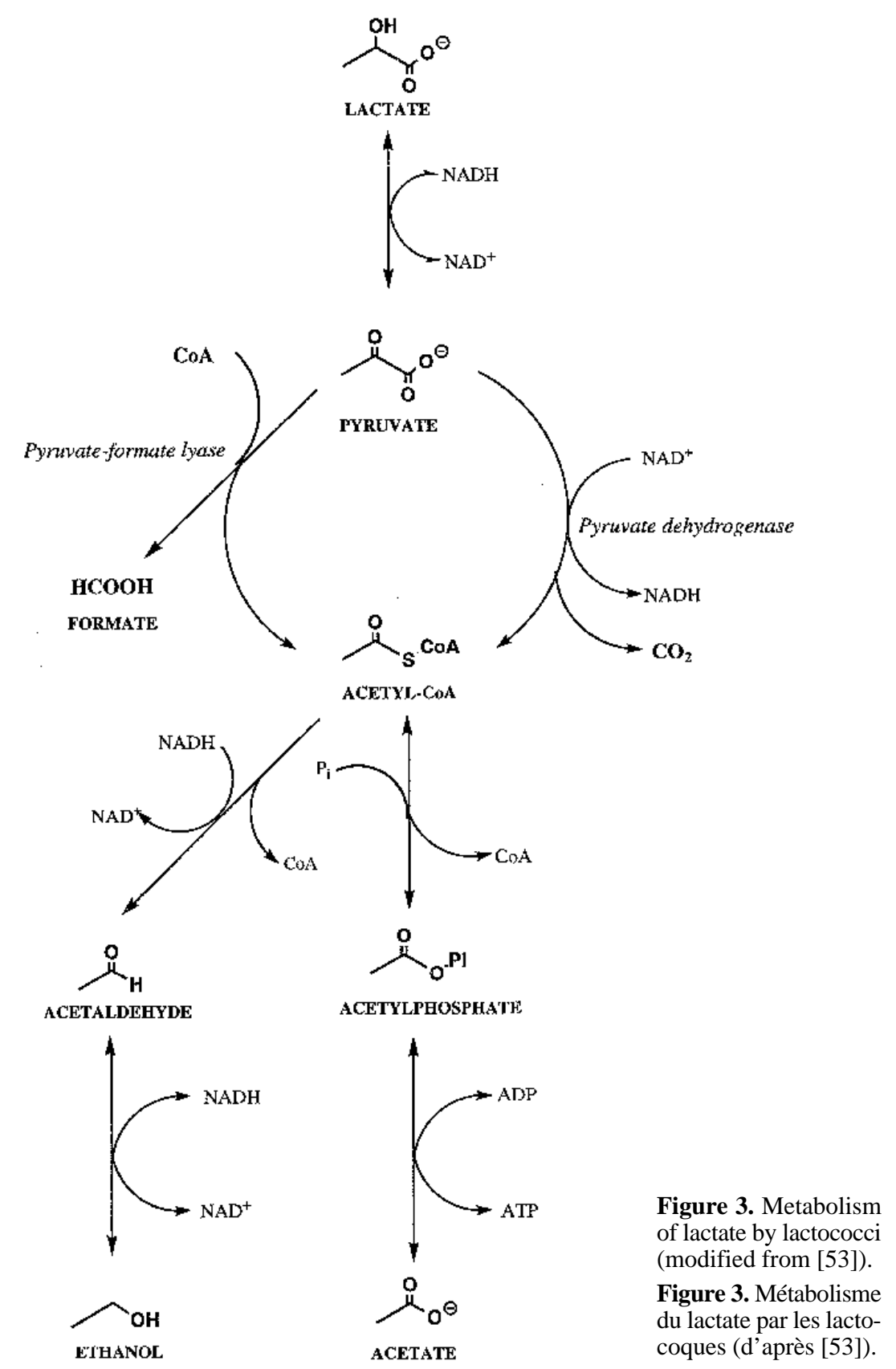


extent in cheese due to its low redox potential (ca. $-250 \mathrm{mV}$ ). Acetate, an important flavour compound in many cheeses, in addition to being formed from lactose by lactic acid bacteria (LAB) may also be formed as a result of citrate and lactate metabolism (see below), or as a product of the catabolism of amino acids.

Propionibacterium sp. in Swiss-type cheeses grow once the cheeses are transferred into the warm-room after brining and preferentially metabolize L-lactate to propionate, acetate and $\mathrm{CO}_{2}$ (see Scheme 2). The carbon dioxide produced is essential for eye development; and propionate and, to a lesser extent, acetate contribute to the flavour of these cheeses. Fermentation of lactose and lactate in Swiss-type cheeses has been described by Steffen et al. [132] and Turner et al. [137].

Late gas blowing and off-flavours in certain hard cheeses result from the metabolism of lactate (or glucose) by Clostridium sp. to butyric acid and $\mathrm{H}_{2}$ ([53]; Fig. 4). These defects may be avoided by good hygiene, addition of $\mathrm{NO}_{3}^{-}$or lysozyme, or by the physical removal of spores by bactofugation or microfiltration.

Metabolism of lactate is most extensive in surface mould-ripened cheeses, e.g., Camembert and Brie $[67,81,106]$. The mesophilic starter bacteria produce lactic acid in the curd (ca. 1\%), which is quickly metabolized by secondary microorganisms (initially Geotrichum candidum and Debaryomyces hansenii, followed later by Penicillium camemberti and perhaps coryneform bacteria like Brevibacterium linens). The yeasts and moulds rapidly metabolize lactate to $\mathrm{CO}_{2}$ and $\mathrm{H}_{2} \mathrm{O}$, and the $\mathrm{pH}$ of the cheese surface increases. When the lactate has been exhausted, $P$. camemberti metabolizes amino acids released from the caseins with the production of $\mathrm{NH}_{3}$ [56]. Deacidification of the cheese surface has a major impact on the growth of coryneform bacteria $(\mathrm{Br}$. linens does not grow below $\mathrm{pH}$ 5.8), plasmin activity (which is optimum at alkaline $\mathrm{pH}$ ) and has a major effect on cheese texture since $\mathrm{Ca}^{2+}$ precipitates at the surface as $\mathrm{Ca}_{3}\left(\mathrm{PO}_{4}\right)_{2}$, causing a $\mathrm{Ca}^{2+}$ gradient to develop within the cheese. Similar deacidification occurs in smear-ripened cheeses by metabolism of lactate by yeasts and moulds which initially dominate the surface microflora. Deacidification is essential for the growth of coryneform bacteria, which dominate the smear during ripening and are responsible for the characteristic flavour of these cheeses $[93,120]$.

Milk contains ca. $8 \mathrm{mmol} \cdot \mathrm{L}^{-1}$ citrate, most of which is lost in the whey during cheesemaking, since ca. $94 \%$ of the citrate is in the soluble phase of the milk. Nevertheless, the low concentration of citrate in cheese curd $\left(10 \mathrm{mmol} \cdot \mathrm{kg}^{-1}\right)$ is of great importance since it may be metabolized to a number of volatile flavour compounds by certain mesophilic starters (citrate-positive, $\mathrm{Cit}^{+}$, lactococci and Leuconostoc sp.) by pathways summarized in Figure 5. Citrate is not metabolized by $S$. thermophilus nor by thermophilic lactobacilli, but is metabolized by certain mesophilic lactobacilli in the NSLAB flora. Citrate metabolism has been reviewed by several researchers $[25,26,51$, 61]. $\mathrm{Cit}^{+}$microorganisms do not utilize citrate as an energy source, but rather it is cometabolized with lactose or some other sugar. The gene encoding the citrate transport mechanism is plasmid-encoded. The principal flavour compounds produced on

Scheme 2.

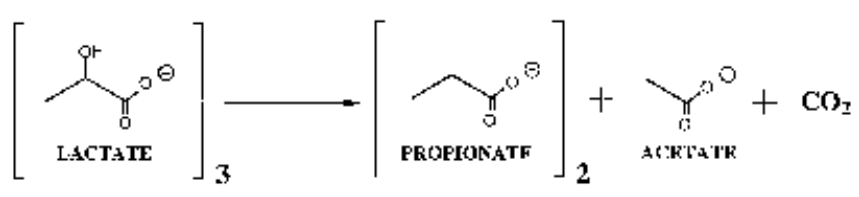



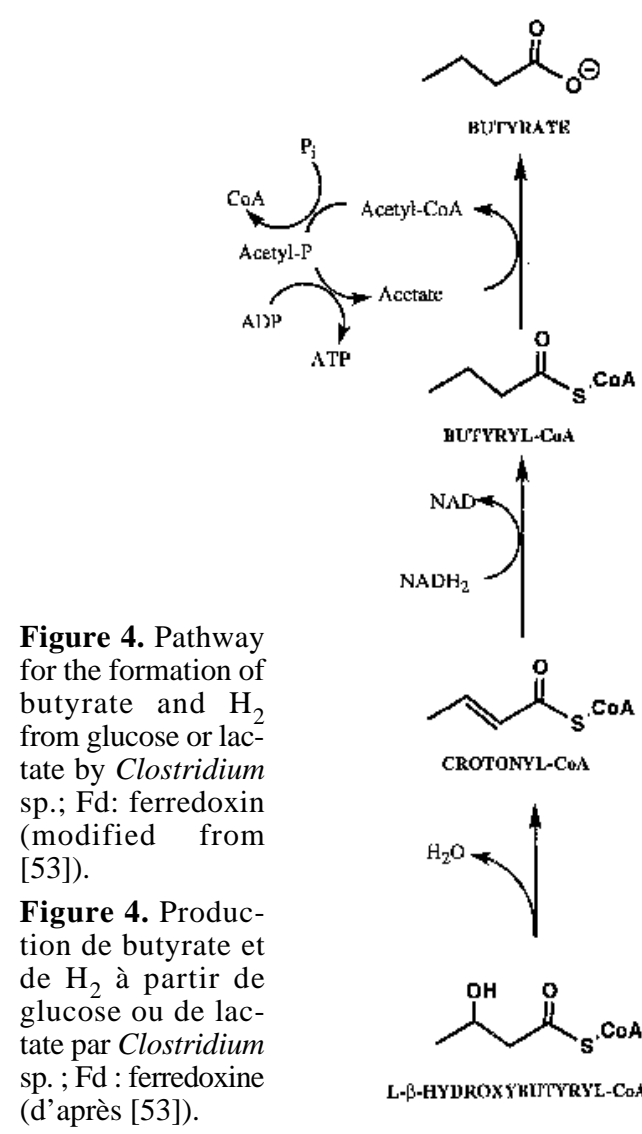

Figure 4. Pathway

for the formation of

butyrate and $\mathrm{H}_{2}$

trom

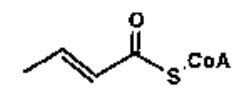

CROTONYL-Con

Fd: ferredoxin

[53])

4. Produc-

tion de butyrate et

- $\mathrm{H}_{2}$ à partir de

$\mathrm{H}_{2} \mathrm{O}-$

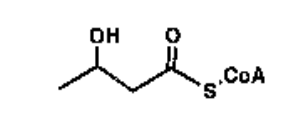

L-P-HYDKOXYHTTYYYE-CaA
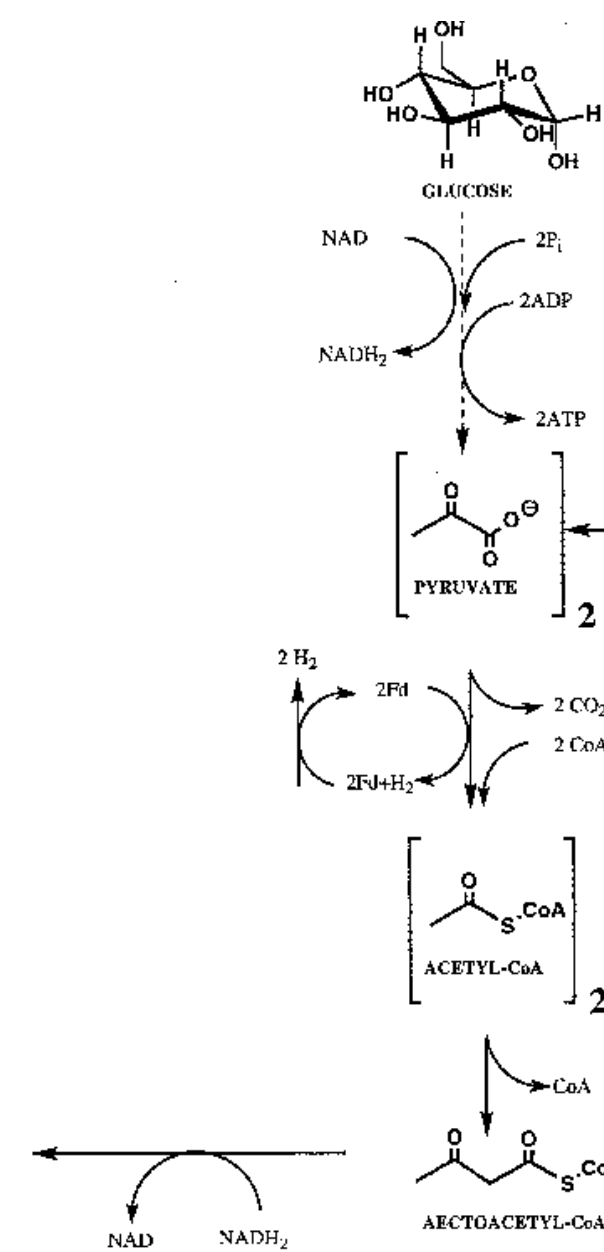

guccose

NAD

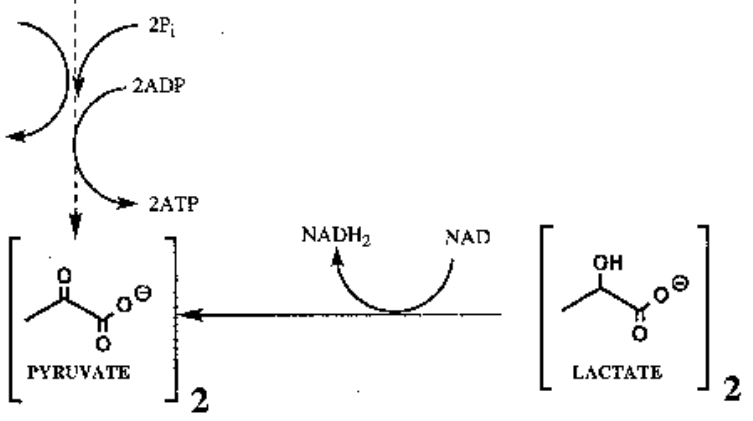

$({ }_{2 \mathrm{~N}+\mathrm{H}_{2}}^{2 \mathrm{Fd}} \overbrace{}^{2 \mathrm{H}_{2}}$

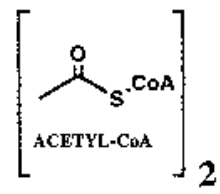

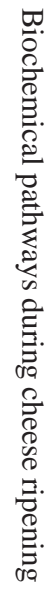

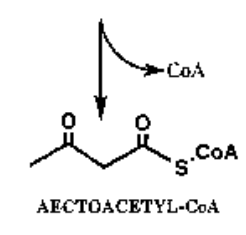




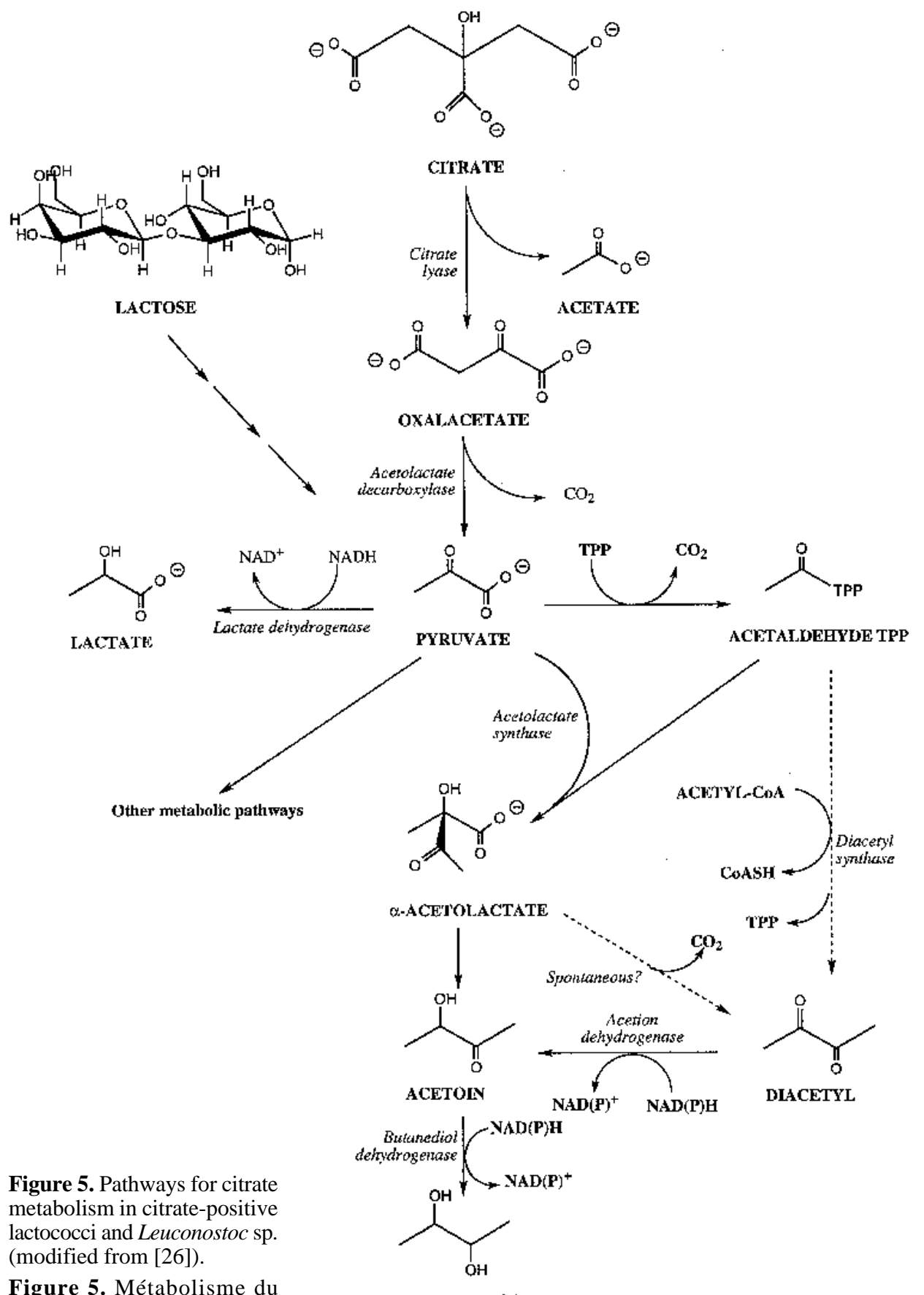
citrate-positives et Leuconos2,3-BUTANEDIOL toc sp. (d'après [26]). 
metabolism of citrate are acetate, diacetyl, acetoin and 2,3-butanediol. Diacetyl is usually produced only in small amounts (1-10 $\mu \mathrm{g} \cdot \mathrm{mL}^{-1}$ in milk), but acetoin is generally produced in much higher quantities (10-50fold higher than diacetyl concentrations). Acetate is produced from citrate in equimolar concentrations. Production of 2,3-butanediol by starters has not been studied in detail. Despite its importance, the exact reactions which result in the formation of diacetyl remain unclear. Diacetyl could be produced directly from acetaldehyde-thiamine pyrophosphate (TPP) and acetyl-CoA by enzymic action, but diacetyl synthase has never been identified clearly in LAB. Alternatively, $\alpha$-acetolactate, formed from the reaction of pyruvate and acetaldehyde-TPP, is very unstable and could be decarboxylated non-oxidatively to form acetoin, or oxidatively to form diacetyl. However, since the oxidation-reduction potential of cheese (ca. $-250 \mathrm{mV}$ ) is low, it is not clear how diacetyl could be produced oxidatively by starter cultures. Acetoin is produced from $\alpha$-acetolactate by the action of acetolactate decarboxylase. Products of citrate metabolism produced by pure cultures of $\mathrm{Cit}^{+}$ lactococci and Leuconostoc sp. differ: the former produce diacetyl, acetoin and $\mathrm{CO}_{2}$ in addition to lactate, but the latter produce large amounts of lactate and acetate. Pure cultures of Leuconostoc sp. do not produce acetoin or diacetyl because pyruvate is an intermediate of both lactose and citrate metabolism and the pyruvate produced from citrate metabolism is converted to lactate and acetylphosphate (via acetyl-CoA). Acetate is produced from acetylphosphate with the concomitant production of $1 \mathrm{~mol}$ ATP, resulting in faster growth of the microorganism. In mixed cultures, Leuconostoc sp. produce diacetyl and acetoin, perhaps because their ability to take up lactose is greatly reduced below $\mathrm{pH}$ 5.5.

Citrate metabolism is of particular importance in Dutch-type cheeses where the $\mathrm{CO}_{2}$ produced is responsible for eye formation. Carbon dioxide produced by citrate fer- mentation can cause undesirable openness and the 'floating curd' defect in Cheddar and Cottage cheeses. Diacetyl is an important aroma compound in a number of varieties, including Dutch-type cheeses, Quarg and Cottage cheese. Diacetyl can be converted to acetoin and 2,3-butanediol and 2-butanone, which are also important flavour compounds in some cheese varieties [30].

\subsection{Lipolysis and metabolism of fatty acids}

Milk fat is essential for the development of the correct flavour in cheese during ripening. Cheddar and other cheeses normally made from whole milk do not develop correct flavour when made from skim milk or milks in which milk fat has been replaced with other lipids [43, 107, 147]. Indeed, satisfactory flavour development is one of the principal problems encountered in the manufacture of reduced-fat variants of established cheese varieties.

As in all high-fat foods, lipids present in cheese can undergo oxidative or hydrolytic degradation. Because of the negative oxidation-reduction potential of cheese, oxidation of cheese lipids is probably limited; but the extent to which it occurs, and its contribution (if any) to cheese flavour development has received little attention [53]. Enzymatic hydrolysis of triglycerides to fatty acids and glycerol, mono- or diglycerides (lipolysis) is, however, essential to flavour development in many cheese varieties. Milk fat contains high concentrations of short- and intermediate-chain fatty acids which, when liberated by lipolysis, contribute directly to cheese flavour. The proportions of free $\mathrm{C}_{6: 0}$ to $\mathrm{C}_{18: 3}$ fatty acids in Cheddar cheese appear to be similar to those in milk fat, but free butyric acid $\left(\mathrm{C}_{4: 0}\right)$ occurs at a greater relative concentration in cheese than in milk fat, suggesting that butyrate is either selectively liberated by lipases present in Cheddar or that it is synthesized by the cheese microflora [12]. The specificity of 
the lipase also influences the development of cheese flavour, since short-chain fatty acids (which have the greatest flavour impact) are generally found at the $s n-3$ position of triglycerides. Cheese $\mathrm{pH}$ also influences the flavour impact of FFA, since carboxylic acids and their salts are perceived differently.

Lipolysis is particularly extensive in hard Italian varieties, surface bacterially-ripened (smear) cheeses and blue mould cheeses (Tab. II), and is essential to correct flavour development in these cheeses. Extensive lipolysis is considered undesirable in many internal, bacterially-ripened varieties such as Cheddar, Gouda and Swiss cheeses; high levels of fatty acids in these cheeses lead to rancidity. However, low concentrations of FFA contribute to the flavour of these cheeses, particularly when they are correctly balanced with the products of proteolysis or other reactions $[15,53,122]$.

Lipases in cheese originate from 6 sources: the milk, rennet preparation (rennet paste), starter, adjunct starter, non-starter bacteria and, if used, exogenous lipases. The origin of lipases in varieties characterized by extensive lipolysis is usually from the coagulant (rennet paste in certain Italian varieties), or from the adjunct starter (mouldripened cheeses). Cheeses which are ripened for very long periods (e.g., Grana-type cheeses) also develop quite high concentrations of FFA.

Milk contains an indigenous lipase (lipoprotein lipase, LPL) in addition to a number of esterases. LPL is the principal indigenous lipase in milk, and has been well characterized (see [108]). It is relatively nonspecific and liberates fatty acids from the $s n-1$ and $s n-3$ positions of mono-, di- or triglycerides and from the $s n-1$ position of phospholipids. The majority (> 80\%) of LPL in bovine milk is associated with the casein micelle and thus is incorporated into the reticulum of the curd. LPL is most important in raw milk cheeses since its activity is reduced by pasteurization, although it probably also makes some contribution to lipolysis in pasteurized-milk cheeses since $78{ }^{\circ} \mathrm{C} \times 10 \mathrm{~s}$ is required for its complete inactivation.

Rennet extracts used in the production of most cheese varieties should be free from lipase activity, but rennet pastes used to coagulate the milk for certain Italian varieties (e.g., Provolone, Romano) contain pregastric esterase (PGE) which is responsible for the extensive lipolysis in these cheeses (see [99]). PGE is secreted by glands at the base of the tongue and is washed into the abomasum with the food. Rennet paste is

Table II. Typical concentrations of free fatty acids (FFA) in some cheese varieties [150, 151].

Tableau II. Concentration en acides gras libres selon le type de fromage [150, 151].

\begin{tabular}{lrlr}
\hline Variety & FFA $\left(\mathrm{mg} \cdot \mathrm{kg}^{-1}\right)$ & Variety & FFA $\left(\mathrm{mg} \cdot \mathrm{kg}^{-1}\right)$ \\
\hline Sapsago & 211 & Gjetost & 1658 \\
Edam & 356 & Provolone & 2118 \\
Mozzarella & 363 & Brick & 2150 \\
Colby & 550 & Limburger & 4187 \\
Camembert & 681 & Goat's milk & 4558 \\
Port Salut & 700 & Parmesan & 4993 \\
Monterey Jack & 736 & Romano & 6754 \\
Cheddar & 1028 & Blue-mould (US) & 32230 \\
Gruyère & 1481 & Roquefort & 32453 \\
\hline
\end{tabular}


prepared from partially-dried abomasa by grinding them into a paste. Rennet pastes are added to cheese milk as slurry (in water or milk). PGE is a $49 \mathrm{~kg} \cdot \mathrm{mol}^{-1}$ glycoprotein which is highly specific for short-chain fatty acids at the $s n-3$ position. Because of hygienic concerns regarding rennet pastes, fungal lipases have been investigated as alternatives (see [45, 48]).

The lipase/esterase systems of starter bacteria have received much less attention then their proteolytic systems. Lactococcus sp. are only weakly lipolytic, but lactococci may be responsible for the liberation of quite high levels of FFA when present in high cell numbers or over extended ripening periods. Lipases/esterases of Lactococcus strains, which appear to be intracellular, have been studied $[22,50,53,60]$. Obligately homofermentative lactobacilli used as starters (Lb. helveticus, Lb. delbrueckii subsp. bulgaricus and Lb. delbrueckii subsp. lactis) also produce esterases, some of which have been studied (e.g., [37, 68]). Facultatively heterofermentative lactobacilli (e.g., Lb. casei, Lb. paracasei and Lb. plantarum), which dominate the NSLAB flora of many cheese varieties, are weakly lipolytic. Micrococcus and Pediococcus are also weakly lipolytic [13]. Psychrotrophic bacteria (e.g., Pseudomonas sp.) produce heat-stable lipases which adsorb onto the fat globules in milk and survive pasteurization. They may contribute to lipolysis in cheese made from milk containing high numbers of psychrotrophic bacteria prior to pasteurization [28].

Propionibacterium sp. possess a lipase which contributes to the low extent of lipolysis in Swiss-type cheese [53]. Although lipolysis is relatively extensive in smearripened cheeses, relatively little attention has been focussed on the lipase/esterase systems of coryneform bacteria and the yeasts and moulds which constitute the smear. $B r$. linens have been reported to possess intracellular lipases and esterases [42, 128], and an esterase from $\mathrm{Br}$. linens has been puri- fied and characterized [116]. Penicillium sp. produce potent extracellular lipases which are primarily responsible for the extensive lipolysis in mould-ripened cheeses (see [56]). $P$. camemberti excretes a lipase that is optimally active at about $\mathrm{pH} 9.0$ and $35^{\circ} \mathrm{C}$, while $P$. roqueforti excretes 2 lipases with different substrate specificities that are optimally active between $\mathrm{pH} 6.0$ and 6.5 and at more alkaline $\mathrm{pH}$ values (7.5-9.5), respectively. The impact of FFA on the flavour of blue mould-ripened cheeses is less than for hard Italian varieties, possibly due to neutralization as the $\mathrm{pH}$ increases during ripening, and because of the dominant influence of methyl ketones on the flavour of blue mould cheeses.

In addition to their direct impact on cheese flavour, FFA also act as precursor molecules for a series of catabolic reactions which lead to the production of other flavour compounds (Fig. 6).

The flavour of blue mould cheeses is dominated by alkan-2-ones (2-methyl ketones; see Scheme 3). A homologous series of alkan-2-ones with odd-numbered carbon chains from $\mathrm{C}_{3}$ to $\mathrm{C}_{15}$ (principally heptan-2one, nonan-2-one and undecan-2-one) is produced by the catabolism of FFA by $P$. roqueforti.

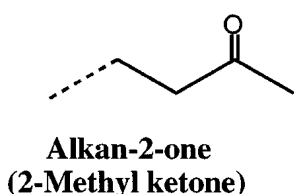

Scheme 3.

The pathway by which alkan-2-ones are produced ( $\beta$-oxidation; Fig. 7 ) involves the release of fatty acids by lipolysis, their oxidation to $\beta$-ketoacids and decarboxylation to alkan-2-ones with one less C-atom. Akan-2ones may be reduced to the corresponding secondary alcohols (alkan-2-ols), a step which is reversible under aerobic conditions. The production of alkan-2-ones in blue mould cheese has been discussed by some researchers $[56,93,95]$. 


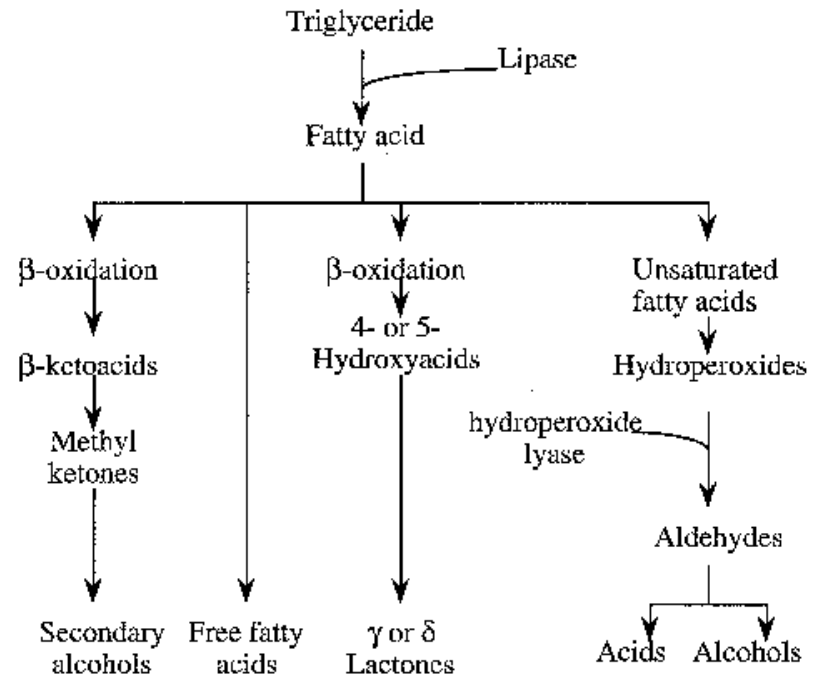

Flavolu compounds

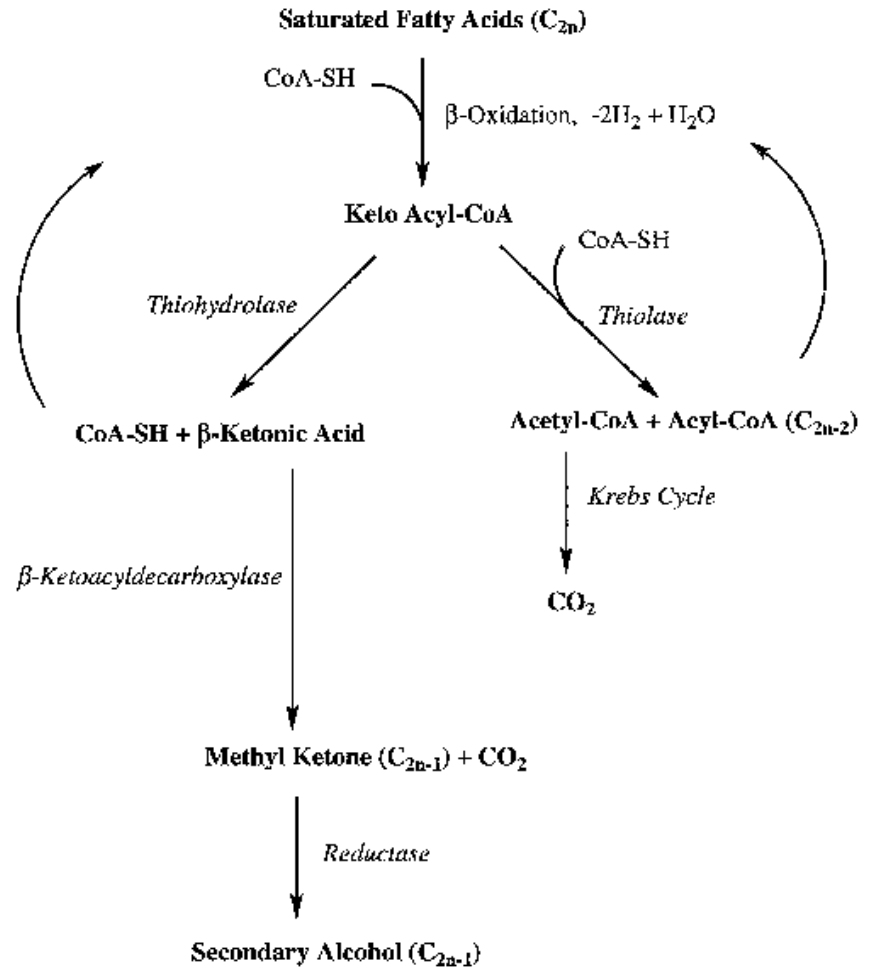

Figure 6. General pathways for the catabolism of free fatty acids in cheese.

Figure 6. Principales voies cataboliques des acides gras libres dans les fromages.
Figure 7. Catabolism of fatty acids by Penicillium roqueforti (modified from [53]).

Figure 7. Catabolisme des acides gras par Penicillium roqueforti (d'après [53]). 


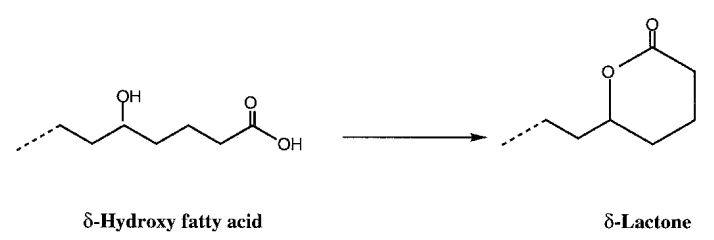

Scheme 4.

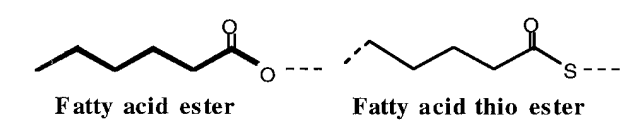

Scheme 5.

In Cheddar, fruity flavour is regarded as a defect by professional cheese graders, although consumers may be prepared to pay a premium for fruity Cheddar. Fourteen different esters have been found in Emmental $[16,17,63,122]$, and esters have also been claimed to be important contributors to the flavour of Parmigiano-Reggiano [94]. The most abundant of the 38 esters identified in Parmigiano-Reggiano are ethyl butanoate, ethyl hexanoate, ethyl acetate, ethyl octanoate, ethyl decanoate and methyl hexanoate [93]. Recently, the formation of new triglycerides in cheese by transesterification has been suggested [133].

\subsection{Proteolysis and related events}

Proteolysis is the most complex and, in most varieties, the most important of the 3 primary events which occur during cheese ripening, and has been the subject of several reviews [46, 47, 49, 53, 55, 115]. The methodology for assessment of the extent and pattern of proteolysis in cheese is of interest as an index of cheese maturity and quality, and has also been reviewed [46, 47, 49, 52, 55, 115].

Proteolysis plays a vital role in the development of: (i) textural changes in the cheese curd, due to breakdown of the protein network, decrease in $a_{\mathrm{w}}$ through water binding by liberated carboxyl and amino groups and increase in $\mathrm{pH}$ (in particular in surface 
mould-ripened varieties); (ii) direct contribution to flavour and perhaps to off-flavour (e.g., bitterness) of cheese through the formation of peptides and free amino acids, FAA; (iii) liberation of substrates (amino acids) for secondary catabolic changes (e.g., deamination, decarboxylation, transamination, desulphuration, catabolism of aromatic compounds such as phenylalanine, tyrosine, tryptophan and reactions of amino acids with other compounds); and (iv) changes to the cheese matrix, which facilitate the release of sapid compounds during mastication.

During ripening, proteolysis in cheese is catalyzed by enzymes from: (i) the coagulant (e.g., chymosin, pepsin, or plant or fungal acid proteinases); (ii) the milk (plasmin, cathepsin D and perhaps other somatic cell proteinases); (iii) the starter; (iv) the nonstarter; or (v) the secondary starter (e.g., $P$. camemberti, $P$. roqueforti, Propionibacterium spp., $B r$. linens and other coryneforms); and (vi) exogenous proteinases and/or peptidases used to accelerate ripening.

In most cheese varieties, the initial hydrolysis of caseins is caused by the coagulant and to a lesser extent by plasmin and perhaps somatic cell proteinases (e.g., cathepsin D), which results in the formation of large (water-insoluble) and intermediate-sized (water-soluble) peptides which are subsequently degraded by the coagulant and enzymes from the starter and non-starter flora of the cheese. The production of small peptides and FAA is caused by the action of microbial proteinases and peptidases.

The coagulants used to clot milk are crude preparations of selected proteinases which often possess a considerable proteolytic activity. Chymosin (EC 3.4.23.4) is the major proteinase in traditional animal rennets (88-94\% milk clotting activity, MCA), with the remainder being pepsin (EC 3.4.23.1; 6-12\% MCA) [121]. The principal role of chymosin (or other coagulants) in cheesemaking is to specifically hydrolyze the Phe ${ }_{105}$-Met ${ }_{106}$ bond of the micelle-stabilizing protein, $\kappa$-casein, during the coagulation of milk. Most of the coagulant activity added to the milk is lost in the whey, but ca. $6 \%$ is retained in the curd depending on factors including coagulant type, cooking temperature and $\mathrm{pH}$ at drainage; residual coagulant contributes to proteolysis in many varieties [29]. In high-cooked cheese (e.g., Emmental), chymosin is denatured extensively and makes relatively little contribution to ripening.

The dominant indigenous milk proteinase, plasmin (fibrinolysin, EC 3.4.21.7), has been the subject of much study (see [9, 58] for reviews). The plasmin system in milk is complex and consists of the active enzyme (plasmin), its zymogen (plasminogen), plasminogen activators, and inhibitors of plasmin (Fig. 8), all of which are present in milk; plasmin, plasminogen and plasminogen activators are associated with the casein micelles in milk, while plasmin inhibitors are in the serum phase. Plasmin is a trypsin-like serine proteinase which is optimally active at about $\mathrm{pH} 7.5$ and $37^{\circ} \mathrm{C}$, and is highly specific for peptide bonds on the C-terminal side of lysyl, and to a lesser extent, arginyl residues [145]. It is particularly active on $\alpha_{\mathrm{s} 2}$ and $\beta$-caseins; hydrolysis of the latter leads to the formation of $\gamma$-caseins (C-terminal fragments) and proteose-peptones (N-terminal fragments) [39]. The specificity of plasmin on $\beta$-casein [35], $\alpha_{\mathrm{s} 2}$-casein $[75,143]$ and $\alpha_{\mathrm{s} 1}$-casein $[76,90]$ in solution has been reported. Milk also contains an acid proteinase, now known to be cathepsin D (EC 3.4.23.5), which is relatively heat-labile (inactivated at $70{ }^{\circ} \mathrm{C}$ $\times 10 \mathrm{~min}$ ), and has a $\mathrm{pH}$ optimum of 4.0 [66]. The specificity of cathepsin D is similar to that of chymosin [92] with preference for $\alpha_{\mathrm{s} 1}$-casein but, surprisingly, this enzyme has very poor milk clotting activity [92]. In rennet free-cheeses, formation of $\alpha_{\mathrm{s} 1}-\mathrm{CN}(\mathrm{f} 24-199)$ has been attributed to the activity of the acid milk proteinase [142]. In addition to cathepsin $\mathrm{D}$, other proteolytic enzymes from somatic cells may also 


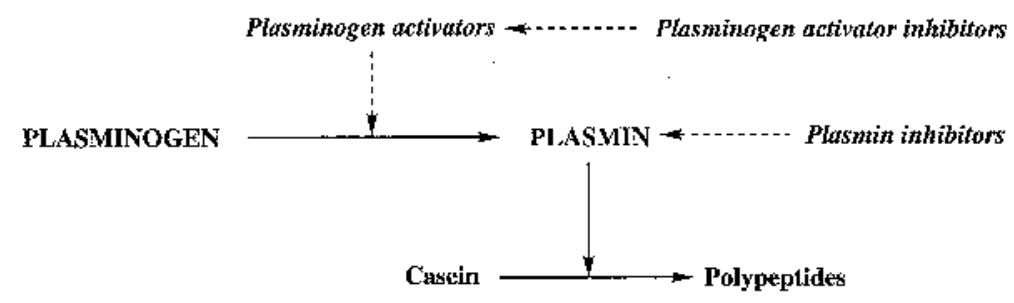

Figure 8. The plasmin system in milk (modified from [9]).

Figure 8. Le système de la plasmine du lait (d'après [9]).

contribute to proteolysis in cheese. Elastase degrades $\alpha_{\mathrm{s} 1}$ - and $\beta$-caseins within $6 \mathrm{~h}$ of incubation, producing a wide range of peptides detectable by urea-polyacrylamide gel electrophoresis (PAGE), and has a broad specificity on $\beta$-casein [27]; it is therefore possible that indigenous elastase in milk may be of significance to proteolysis in cheese, especially cheese produced from raw milk. Somatic cell proteinases are capable of activating plasminogen [141] and thus may influence proteolysis in cheese by elevating plasmin levels.

Although LAB (Lactococcus, Lactobacillus, Streptococcus) are weakly proteolytic, they possess a very comprehensive proteinase/peptidase system that has been studied extensively and reviewed (e.g., [49, $72,73])$. LAB possess a cell envelope-associated proteinase (PrtP), several intracellular oligoendopeptidases (PepO) and (PepF), at least 3 general aminopeptidases (PepN, PepC, PepG), a glutamyl aminopeptidase (PepA), a pyrolidone carboxylyl peptidase (PCP), a leucyl aminopeptidase (PepL), a prolyl-dipeptidyl aminopeptidase (PepX), a proline iminopeptidase (PepI), aminopeptidase $\mathrm{P}(\mathrm{PepP})$, prolinase (PepR), a prolidase (PepQ), a general dipeptidase (PepV) and a general tripeptidase (PepT); they also possess peptide and amino-acid transport systems. This proteolytic system is necessary to enable the $\mathrm{LAB}$ to grow to high numbers in milk $\left(10^{9}-10^{10} \mathrm{cfu} \cdot \mathrm{mL}^{-1}\right)$, which contains only low levels of small peptides and FAA. PrtP contributes to the formation of small peptides in cheese probably by hydrolyzing larger peptides produced from

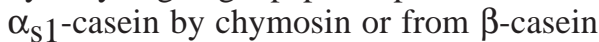
by plasmin, whereas the aminopeptidases, dipeptidases and tripeptidases (which are intracellular) are released after the cells have lysed and are responsible for the production of FAA (Fig. 9).

NSLAB, although present initially at low numbers $\left(<50 \mathrm{cfu} \cdot \mathrm{g}^{-1}\right.$ in Cheddar made from pasteurized milk), grow rapidly to reach $\sim 10^{7} \mathrm{cfu} \cdot \mathrm{g}^{-1}$ within $4 \mathrm{wk}$, and remain relatively constant thereafter [44]. Thus, depending on the rate of death of the starter, NSLAB can dominate the viable microflora of Cheddar, extra-mature Dutch and other cheeses throughout most of the ripening period [49]. NSLAB are particularly important in cheeses made from raw milk. The activity of the NSLAB appears to supplement the proteolytic action of the starter, producing peptides with generally similar molecular weights and FAA [83].

In many cheese varieties, a secondary microflora (secondary starter) is added intentionally and/or encouraged to grow by environmental conditions, and has a diverse range of functions depending on the organisms used. $\mathrm{Cit}^{+}$lactococci and Leuconostoc spp. are used as secondary starters in Dutchtype cheeses, primarily to produce diacetyl, acetoin and $\mathrm{CO}_{2}$. A secondary starter is not used in Cheddar-type cheeses; however, in recent years, Cheddar cheese has been inoculated with selected strains of Lactobacillus (adjunct starter), with the objective of 


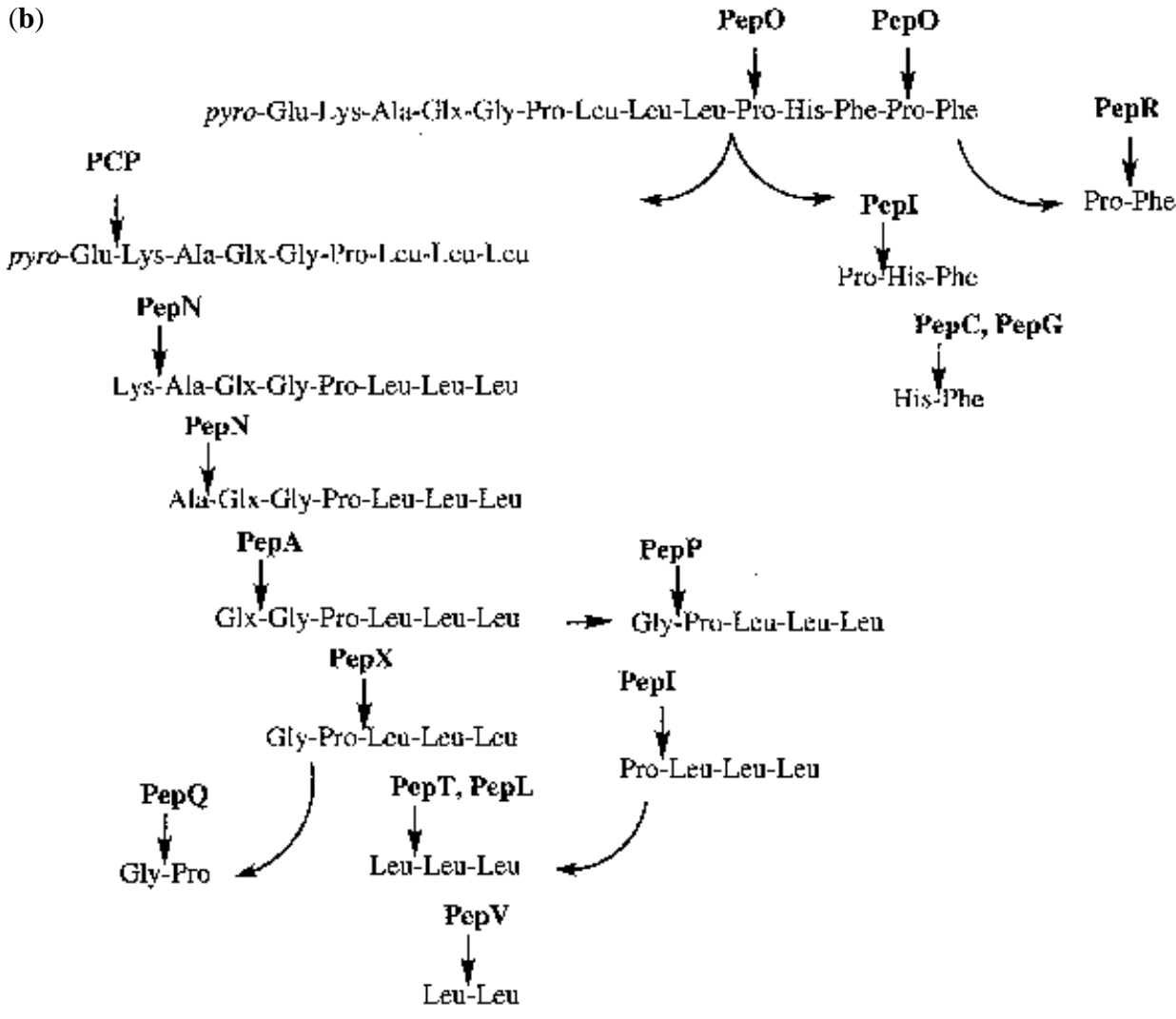

Figure 9. (a) The action of the cell envelope-associated proteinase (PrtP) of Lactococcus on the casein; and (b) degradation of a hypothetical tetrapeptide by the combined action of lactococcal proteinases and peptidases (modified from [53]). PepO: oligoendopeptidase; PepI: prolyl iminopeptidase; PCP: pyrrolidone carboxylyl peptidase; PepN, PepC and PepG: general aminopeptidases; PepL: leucyl aminopeptidase; PepA: glutamyl aminopeptidase; PepX: X-prolyl-dipeptidyl aminopeptidase; PepR: prolinase; PepQ: prolidase; PepV: dipeptidase; and PepT: tripeptidase.

Figure 9. (a) Action de la protéase membranaire (PrtP) de Lactococcus sur les caséines et (b) mécanisme de dégradation d'un tétrapeptide hypothétique par l'action combinée de protéases et de peptidases de lactocoques (d'après [53]). PepO : oligoendopeptidase ; PepI : prolyl iminopeptidase ; PCP : pyrrolidone carboxylyl peptidase ; PepN : PepC et PepG, aminopeptidases générales ; PepL : leucyl aminopeptidase ; PepA : glutamyl aminopeptidase ; PepX : X-prolyl-dipeptidyl aminopeptidase ; PepR : prolinase ; PepQ : prolidase ; PepV : dipeptidase ; PepT : tripeptidase. 
accelerating ripening and accentuating flavour (see $[19,91]$ ). The proteolytic system of traditional secondary starters, i.e., $P$. roqueforti (blue cheeses), $P$. camemberti (Camembert and Brie), Propionibacterium spp. (Swiss cheeses), and Br. linens (surface smear-ripened cheeses) has been reviewed by Fox and McSweeney [49]. $B r$. linens secretes an extracellular proteinase and an aminopeptidese and possesses a number of intracellular peptidases, which may be released on cell lysis [117]. These enzymes probably contribute to proteolysis, including the production of free amino acids, on the surface of smear-ripened cheeses. Blueveined cheeses are characterized by the growth of $P$. roqueforti throughout the cheese, and Camembert and Brie by the growth of $P$. camemberti on the surface. Both species produce aspartyl proteinases and metalloproteinases; $P$. camemberti also possesses an intracellular acid proteinase, whereas $P$. roqueforti produces a broad specificity carboxypeptidase, an extracellular metallo-aminopeptidase (see [57]) and amino- and carboxypeptidases [110]. The specificity of the extacellular proteinases from $P$. roqueforti, $P$. camemberti and $B r$. linens on $\alpha_{\mathrm{s} 1}$ - and $\beta$-caseins has been determined (see [53, 118, 119]).

The final products of proteolysis are FAA, the concentrations of which depend on the cheese variety, and which have been used as indices of ripening $[6,89,114]$. The concentration of FAA in cheese at any stage of ripening is the net result of the liberation of amino acids from casein and their transformation to catabolic products. The principal amino acids in Cheddar cheese are Glu, Leu, Arg, Lys, Phe and Ser [147]. Concentrations of amino acids generally increase during ripening, with the exception of Arg, the concentration of which is reported to decrease later in ripening [114]. The level of peptides and FAA soluble in cheese in 5\% phosphotungstic acid (PTA) has been considered to be a reliable indicator of the rate of flavour development $[4,6]$ and the composition of the amino acid fraction and the relative proportions of individual amino acids are thought to be important for the development of the characteristic flavour [19]. However, the relative proportion of individual amino acids appears to be similar in many varieties, and increasing the concentration of FAA in cheese (e.g., through the action of early lysing, lysozyme-treated cells [74], or the use of Lactococcus starter engineered to overproduce PepN $[23,88]$ ) does not accelerate ripening or flavour intensity. Medium and small peptides and FAA contribute to the background flavour of most cheese varieties [139] and some individual peptides have 'brothy', 'bitter', 'nutty' and 'sweet' tastes. The taste descriptor and threshold values of amino acids are summarized in Table III. Fox and Wallace [50] have suggested that flavour and the concentration of FAA could not be correlated, since different cheeses (e.g., Cheddar, Gouda and Edam) have very different flavours, although the concentration and relative proportions of FAA are generally similar. These results show that production of amino acids is not the rate-limiting step in cheese ripening, and it has been suggested [49] that perhaps the enzymatic or chemical modification of amino acids is the critical factor.

\section{Bitterness and other off-flavours}

Bitterness in cheese is due mainly to hydrophobic peptides and is generally regarded as a defect, although bitter notes may contribute to the desirable flavour of mature cheese. The literature concerning bitterness in dairy products has been reviewed by Lemieux and Simard [79, 80] and McSweeney et al. [93]. Certain sequences in the caseins are particularly hydrophobic and, when excised by proteinases, can lead to bitterness. The action of coagulant has been implicated in the formation of bitter peptides in cheese, and thus factors that affect the retention and activity of rennet in the curd may influence the development of bitterness. The starter and rennet type are considered important in the development of 
Table III. Taste descriptor and threshold values of amino acids [93].

Tableau III. Descripteurs et seuils de perception des acides aminés [93].

\begin{tabular}{|c|c|c|c|c|c|c|c|c|c|}
\hline \multirow{2}{*}{$\begin{array}{l}\text { Amino } \\
\text { Acid }\end{array}$} & \multirow{2}{*}{$\begin{array}{c}\mathrm{Q} \\
\left(\mathrm{cal} \cdot \mathrm{mol}^{-1}\right)\end{array}$} & \multirow{2}{*}{$\begin{array}{c}\text { Taste } \\
\text { threshold } \\
\left(\mathrm{mg} \cdot 100 \mathrm{~mL}^{-1}\right)\end{array}$} & \multirow{2}{*}{$\begin{array}{l}\text { Concentration }^{\mathrm{a}} \\
\text { in Cheddar } \\
\left(\mu \mathrm{g} \cdot \mathrm{g}^{-1}\right)\end{array}$} & \multirow[t]{2}{*}{ Perception $^{\mathrm{b}}$} & \multicolumn{5}{|c|}{ Taste } \\
\hline & & & & & Sweet & Salt & Sour & Bitter & Umami \\
\hline Gly & 0 & 130 & 371 & - & $* * *$ & & & & \\
\hline Ser & -300 & 150 & 1210 & - & $* * *$ & & & & $*$ \\
\hline Thr & 400 & 260 & 649 & - & $* * *$ & & & $*$ & \\
\hline His & 500 & 20 & 436 & \pm & & & $* * *$ & & \\
\hline Asp & 0 & 3 & 606 & + & & & $* *$ & & $*$ \\
\hline Glu & 0 & 5 & 5075 & + & & & $* * *$ & & $* *$ \\
\hline Arg & 750 & 50 & 1737 & + & & & & $* * *$ & \\
\hline Ala & 500 & 60 & 337 & - & $* * *$ & & & & \\
\hline Met & 1300 & 30 & 869 & + & & & & $* * *$ & \\
\hline Lys & 1500 & 50 & 2330 & + & $* *$ & & & $* *$ & \\
\hline Val & 500 & 40 & 2022 & + & & & & $* * *$ & \\
\hline Leu & 1800 & 190 & 4610 & \pm & & & & $* * *$ & \\
\hline Pro & 2600 & 300 & 389 & - & $* * *$ & & & $* * *$ & \\
\hline Phe & 2500 & 90 & 2400 & + & & & & $* * *$ & \\
\hline Tyr & 2300 & - & 607 & & & & & $* * *$ & \\
\hline Ile & 2950 & 90 & 466 & - & & & & $* * *$ & \\
\hline Trp & 3400 & 90 & - & & & & & $* * *$ & \\
\hline
\end{tabular}

a [148]; 6 month-old Cheddar, total concentration $24.1 \mathrm{mg} \cdot \mathrm{g}^{-1}$ cheese.

b Amino acids in Cheddar are considered to be perceived if their concentration in a water extract (50 g cheese containing $37 \%$ moisture to $100 \mathrm{~mL}$ water) is greater than their threshold concentration.

${ }^{\text {a }}$ Cheddar âgé de 6 mois, concentration totale $24,1 \mathrm{mg} \cdot \mathrm{g}^{-1}$ fromage.

${ }^{\mathrm{b}}$ Il est généralement admis que les acides aminés sont perçus dans le Cheddar si leur concentration dans la phase acqueuse $(50 \mathrm{~g}$ de fromage à $37 \%$ d'humidité additionnés de $100 \mathrm{~mL}$ d'eau) est plus élevée que leur seuil de perception. 
bitterness; Lawrence et al. [77] have suggested that the major role of rennet in the development of bitterness may be the production of long peptides that will be subsequently degraded to small bitter peptides by starter proteinases. Coagulants and certain strains of starter and Penicillium spp. have been associated with the development of bitterness, and it would appear that bitterness in cheese results from the action of coagulant on casein with the release of bitter peptides. Bitter peptides may also be produced directly by the starter. These peptides accumulate in cheese due to the absence of proteinases or peptidases from the starter, or due to the inability of 'bitter' starters to hydrolyze them to non-bitter peptides that otherwise would be too large to be perceived as bitter [79]. Low-fat cheeses have been reported to develop bitterness [8], although in full-fat cheese, a certain proportion of bitter peptides, being hydrophobic, are less likely to be perceived as being bitter, perhaps due to their partition into the fat phase.

In addition to peptides, a number of other compounds can contribute to bitterness in cheese, including amino acids, amines, amides, substituted amides, long-chain ketones and some monoglycerides [2]. The origin of 'unclean' and related flavours in Cheddar has been attributed to a number of Strecker-type compounds [34], including phenylacetaldehyde, phenylethanol, 3-methylbutanol, 2-methylpropanol, phenol, and $p$-cresol (see below). Off-flavours (rancidity) can be due to excessive or unbalanced lipolysis caused by lipases/esterases from starter or non-starter LAB, enzymes from psychrotrophs in the cheese milk, or indigenous milk lipoprotein lipase.

\section{CATABOLISM OF AMINO ACIDS AND RELATED EVENTS}

Catabolism of FAA can result in a number of compounds, including ammonia, amines, aldehydes, phenols, indole and alcohols, all of which may contribute to cheese flavour. Catabolism of FAA probably plays some role in flavour development in all varieties, but it is particularly significant in mould and smear-ripened cheeses [53]. The first stage in amino-acid catabolism involves decarboxylation, deamination, transamination, desulphuration or perhaps hydrolysis of the amino-acid side-chains. The second stage involves conversion of the resulting compounds (amines and $\alpha$-ketoacids), as well as amino acids themselves, to aldehydes, primarily by the action of deaminases on amines. The final stage of amino-acid catabolism is the reduction of the aldehydes to alcohols, or their oxidation to acids. Sulphur-containing amino acids can undergo extensive conversion, leading to the formation of a number of compounds, including methanethiol and other sulphur derivatives. General pathways for the catabolism of FAA are summarized in Figure 10, and the subject has been reviewed by some researchers $[6$, $50,53]$. Despite the importance of these pathways, detailed information on these reactions and the agents responsible for their production is limited. Recently, a summary of the amino acid catabolic pathways identified in LAB has been reported [24]; however, for many of these pathways, it is not known to what extent they occur in cheese.

\subsection{Production of amines and pyrazines}

Decarboxylation involves the conversion of an amino acid to the corresponding amine with the loss of carbon dioxide. Amines, including biogenic amines, are produced in cheese by enzymatic decarboxylation of FAA [65]; the relative concentration of each amine depends on the cheese variety and the non-starter microflora. The principal amines in most cheeses are tyramine and histamine (see Scheme 6) produced by decarboxylation of Tyr and His, respectively $[53,124]$, and increasing concentrations of these amines in Cheddar cheese inoculated with adjunct lactobacilli has indicated that 


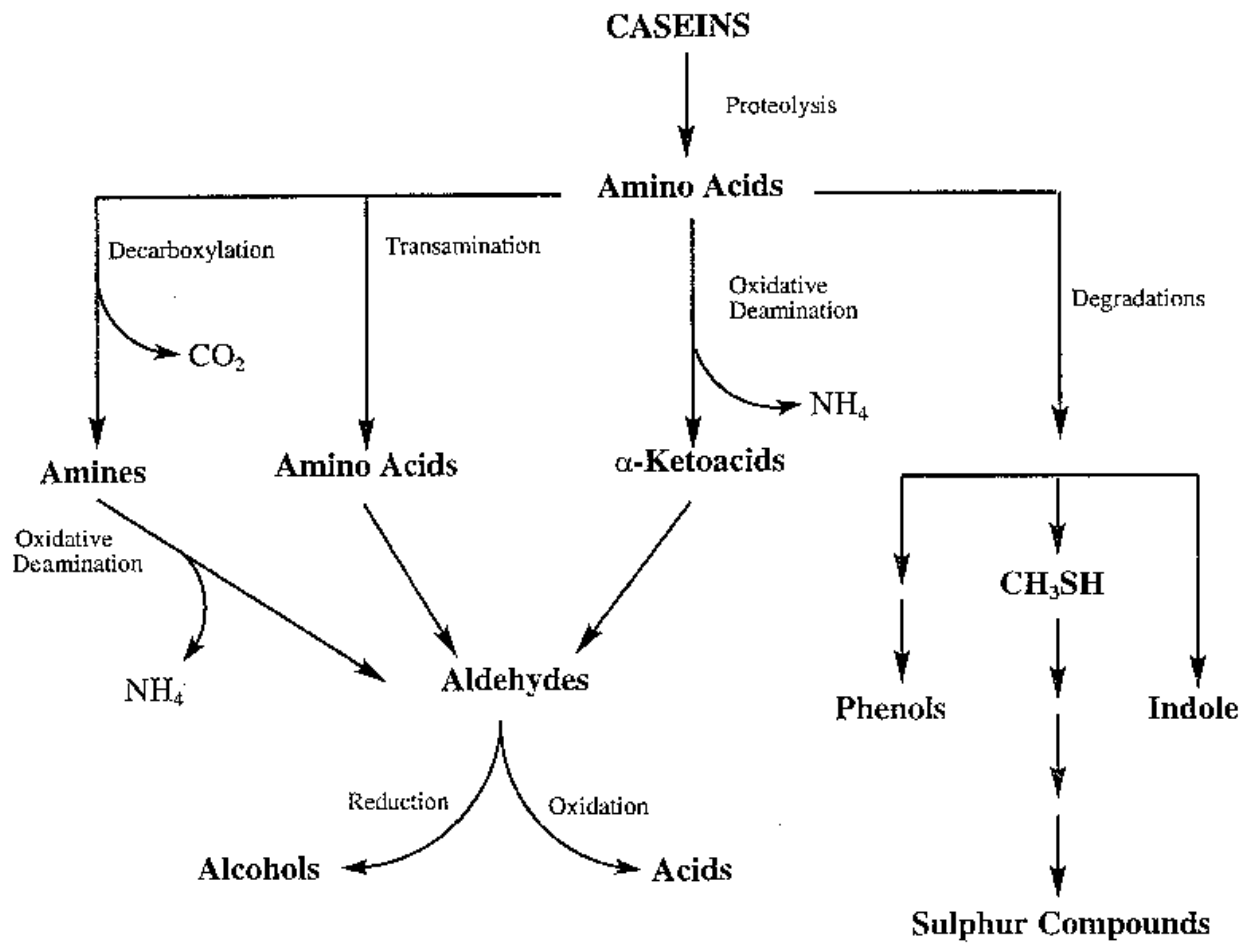

Figure 10. General pathways for the catabolism of FAA (modified from [59]).

Figure 10. Principales voies cataboliques des acides aminés libres (d'après [59]).

decarboxylases of lactobacilli may play a role in their production [19]. Histamine when present at high levels can result in food poisoning [123], and some cases of histamine poisoning have occurred subsequent to the consumption of cheese [135] Fourteen amines (primary and secondary) have been found in Cheddar cheese [102], and 8 amines in German blue-mould cheese [103].

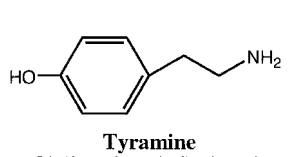

[4-(2-aminoethyl) phenol]

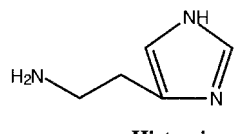

Histamine [2-(4-imidazoly1)ethylamine]

Scheme 6.

Ney [101] reported the presence of acetamide, propionamide, butyramide, isobutyramide and isovaleramide in Cheddar, Emmental, Edelpilzkäse (a German blue-mould variety) and Manchego cheese. Numerous volatile amines have been identified in Camembert cheese: methylamine, ethylamine, $n$-propylamine, isopropylamine, $n$-butylamine, 1 -methylpropylamine, $n$-amylamine, iso-amylamine, anteiso-amylamine, $n$-hexylamine, ethanolamine, dimethylamine, diethylamine, dipropylamine and dibutylamine $[1,95]$. No relationship has been found between the concentration of FAA and the production of amines in cheese [127], probably due to differences in the rates of decarboxylation of individual amino acids or in the rate of deamination of resulting amines [112]. Simple decarboxylation can explain the formation of most amines found in cheese, but there is no readily 
available explanation for the formation of secondary and tertiary amines in cheese [2].

Liardon et al. [82] found 2,5-dimethylpyrazine, 2,6-dimethylpyrazine, ethylpyrazine, 2,3-dimethylpyrazine, ethylmethyl-pyrazine, trimethylpyrazine, tetramethylpyrazine and ethyltrimethylpyrazine in the outer layer (including the smear) of Swiss Gruyère cheese, where they were presumably formed by the microorganisms in the smear. Pyridine, pyrazine, 2,3-dimethylpyrazine, 2,6-dimethylpyrazine, 2-ethyl3,5(6)-dimethylpyrazine and 2,3-diethyl-5methylpyrazine were found in Parmesan [94]; 6 alkyl pyrazines were also found in Swiss Emmental; the fraction containing these compounds had a burnt-potato odour [126].

\subsection{Deamination and formation of neutral or acidic compounds}

Deamination of FAA leads to the production of ammonia and $\alpha$-keto acids [59]. Ammonia is an important constituent in many cheeses such as Camembert, Gruyère and Comté [53], and P. camemberti, G. candidum and $\mathrm{Br}$. linens play a major role in ammonia production [67]. Amines can be subjected to oxidative deamination, yielding aldehydes [95]. $\alpha$-Keto acids corresponding to almost every amino acid have been reported in Cheddar [102], Emmental or German blue-mould cheeses [103], Manchego, Parmesan, Gouda, Provolone, Camembert [104] and Fontina [105]. $\alpha$-Keto-3-methylbutanoic and $\alpha$-keto-3methylpentanoic acids have been reported to have an intense cheese-like odour [98], but the concentrations of these acids vary widely between cheeses. However, more recent studies have not identified $\alpha$-keto acids in cheese, maybe due to the fact that these compounds are difficult to analyze by gas chromatography, whereas Ney and Wirotama [105] formed the 2,4-dinitrophenylhydrazone derivatives, which they then reduced to the corresponding amino acids and quantified [100].

\subsection{Transamination, the Strecker reaction and production of aldehydes}

Aldehydes may be produced as a result of amino acid catabolism (Fig. 10) [53]. Enzyme-catalyzed transamination of FAA results in the formation of an intermediate imide that is subsequently degraded by decarboxylation or by the Strecker reaction [95, 139], forming an aldehyde [53, 112]. At the beginning of cheese ripening, with a lower $\mathrm{pH}$, amino acids are decarboxylated to amines. In the later stages of ripening when there is an increase in $\mathrm{pH}$, these amines are subsequently oxidized to aldehydes via the Strecker degradation [10]. Aldehydes do not accumulate to high concentrations in cheese because they are rapidly transformed to alcohols or to the corresponding acids $[34,80]$. Aldehydes are thought to contribute to the flavour of many cheese varieties, including Cheddar [34] and Parmesan [10]. Although unclean flavours develop when the concentrations of Strecker-derived compounds exceed a certain threshold in Cheddar, no correlation between the concentrations of Strecker-derived compounds and concentrations of individual FAA have been found in cheese [34]. Phenylacetaldehyde, isobutanal, 3-methylbutanal and methional can be formed by this mechanism from Phe, Leu/Ile, Val and Met, respectively [2]; acetaldehyde can be derived from threonine with the help of a threonine aldolase, and ethanal can be produced by yeasts when alcohol dehydrogenase is less active than pyruvate decarboxylase [95]. Benzaldehyde may be produced from the $\alpha$-oxidation of phenylacetaldehyde or from $\beta$-oxidation of cinnamic acid $[20,125]$. The Strecker reaction and the structures of some Strecker aldehydes are shown in Figure 11.

\subsection{Catabolism of sulphur amino acids}

Sulphur compounds found in cheese must originate principally from methionine, as there are higher concentrations of Met in 
(a)

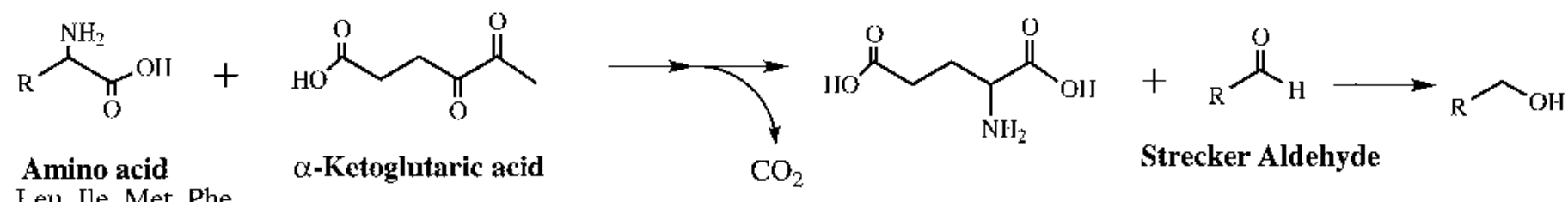
Val, Leu, Ile, Met, Phe

$\alpha$-Ketoglutaric acid

$$
\mathrm{CO}_{2}
$$

\section{Strecker Aldehyde}

Figure 11. The Strecker reaction between an $\alpha$-amino acid and an $\alpha$-keto acid (e.g., $\alpha$-ketoglutaric acid) (a), and the structure of some Strecker aldehydes found in cheese $(\mathbf{b})$.

Figure 11. Réaction de Strecker entre un acide aminé $\alpha$ et un acide cétonique $\alpha$ (ex. acide $\alpha$-cétoglutarique) (a) et structure de quelques aldéhydes formés par la réaction et retrouvés dans les fromages (b). 
caseins than cysteine (Cys residues in the caseins are present at low levels only in $\alpha_{\mathrm{s} 2}$ and $\kappa$-caseins). Possible pathways suggested in the literature for the catabolism of Met and the structures of volatile sulphur compounds found in cheese are shown in Figure 12. The catabolic products of sulphur amino acids have been implicated as major contributors to the flavour of Cheddar and many other cheese varieties, but their importance in smear and surface-ripened cheeses appears to be accentuated by their high concentration in the surface smear $[2,14,34$, 57]. Low molecular weight sulphur compounds in cheese include methanethiol $\left(\mathrm{CH}_{3} \mathrm{SH}\right)$, hydrogen sulphide $\left(\mathrm{H}_{2} \mathrm{~S}\right)$, dimethylsulphide (DMS; $\mathrm{CH}_{3} \mathrm{SCH}_{3}$ ), dimethyldisulphide (DMDS; $\mathrm{CH}_{3} \mathrm{SSCH}_{3}$ ), dimethyltrisulphide (DMTS; $\mathrm{CH}_{3} \mathrm{SSSCH}_{3}$ ) and carbonyl sulphide $(\mathrm{O}=\mathrm{C}=\mathrm{S})$. Sulphur compounds are thought to interact with each other and with other compounds in cheese, generating other volatile flavour compounds [69].

Methanethiol is present in Camembert together with other sulphur compounds, such as 2,4-dithiapentane, 3,4-dithiahexane, 2,4,5-trithiahexane and 3-methylthio-2,4dithiapentane, and these compounds are responsible for the garlic note which can be found in well-ripened Camembert cheese [3]. Br. linens is one of the principal microorganisms found on the surface of smear-ripened cheeses, is also present on the surface of mould-ripened varieties (e.g., Camembert), and can produce methanethiol enzymatically. In cheeses such as Cheddar, which lacks a surface microflora, flavour is produced by starter and non-starter bacteria and their enzymes, and the production of methanethiol is thought to be a chemical process [69]; however, Urbach [139] suggested that the secondary flora, particularly in Cheddar and Emmental, are likely to be more important than chemical reactions for the formation of sulphur compounds. Dimos et al. [30] showed that the concentration of methanethiol in full-fat and reduced-fat Cheddar was highly correlated with flavour, indicating that the lack of flavour in reducedfat Cheddar is due mainly to the lack of methanethiol.

Although the exact pathway for the nonenzymatic formation of $\mathrm{CH}_{3} \mathrm{SH}$ has not been established, a mechanism proposed by Manning $[84,85]$, in which a reducing agent produces $\mathrm{H}_{2} \mathrm{~S}$ from cystine/cysteine, which then reacts with methionine to produce methanethiol, is accepted by many investigators $[2,53,59]$.

The concentration of $\mathrm{H}_{2} \mathrm{~S}$ in cheese increased during ripening, and initially no correlation was found between its concentration (or those of other sulphur compounds) and flavour development [6], although Barlow et al. [11] found a high correlation between the concentration of $\mathrm{H}_{2} \mathrm{~S}$ and flavour, particularly when the value for $\mathrm{H}_{2} \mathrm{~S}$ was combined with either the concentration of water-soluble nitrogen (WSN) or lactic acid. These authors suggested that these parameters $\left(\mathrm{H}_{2} \mathrm{~S}\right.$ and WSN/lactate) were better predictors of the future quality of young cheeses than their flavour or composition at an early age. The presence of $\mathrm{H}_{2} \mathrm{~S}$ in fresh curd indicates that some may also be formed during pasteurization of cheese milk [74]. DMS, DMDS and DMTS are thought to be important contributors to cheese flavour $[10,14]$. DMS is a product of the metabolism of propionic acid bacteria formed from Met, and is a component of Swiss cheese flavour [2]. DMS concentrations in Cheddar cheese remain constant for up to 6 months, but decrease thereafter [6]. DMDS can be formed as an end-product of Strecker degradation, and has been identified in Parmesan [10], Cheddar [6, 11], and surface-ripened cheeses [64]. DMDS concentrations in Cheddar correlate reasonably well with flavour scores [11]. DMTS has been associated with the aroma of cooked cabbage, broccoli, or cauliflower, and has been identified in Parmesan [10] and Cheddar [152] cheeses. DMS and DMDS could be produced directly from methanethiol, but it is unclear how DMTS is produced in cheese. 
Figure 12. Sulphur compounds which have been identified in cheese and possible pathways suggested in the literature for the formation of some compounds from methionine.

Figure 12. Composés sulfurés identifiés dans les fromages et ies de ménion

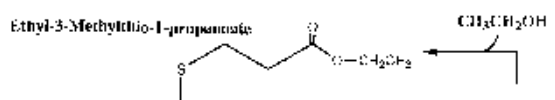


Several other volatile sulphur compounds have been identified in cheese. Methional, which can be produced by Strecker degradation [5], contributes positively to cheese flavour when present at low concentrations, while at high levels, a sweet corn-like offflavour is detectable [10]. Methional, which has been reported to have the odour of raw potatoes [98], has been found among the volatiles from Camembert [33] and premium-quality Cheddar [146]. Ethyl-3methylthio-1-propanoate has been found as a trace component among the volatiles from Parmesan [94]. S-Methylthioacetate can be produced under certain conditions by strains of $\mathrm{Br}$. linens [40, 41], and has been found in Limburger cheese [111]. 3-Methylthiopropanal, presumably formed by transamination of methionine followed by decarboxylation of an intermediate imide, has been identified in Cheddar [2] and Parmesan [10], and may contribute to the aroma of these cheeses. Benzothiazole has been reported to be a component of Parmesan aroma [10], but no mechanism for its formation has been reported. 2,4-Dithiapentane is an important component in Camembert flavour and can be produced by the condensation of methanethiol with formaldehyde [33]. The concentration of carbonyl sulphide increases throughout ripening and is less variable than other sulphur compounds [7], but no correlation has been found between its concentration and cheese flavour.

\subsection{Catabolism of phenylalanine, tyrosine and tryptophan}

Pathways for the catabolism of Trp, Phe and Tyr in LAB are illustrated in Figure 13. Catabolism of Trp (Fig. 13a) produces indole pyruvate, which can be catabolized further to indole lactic acid, indole acetic acid, indole aldehyde and benzaldehyde [54, 62]. Catabolism of Phe (Fig. 13b) results in the formation of phenylpyruvate by the action of an aminotransferase [54]. Phenylpyruvate, phenyl lactate and phenyl acetate have been reported to be detected as metabolites of lactococcal Phe catabolism [153]. Also, nonenzymatic breakdown of phenylpyruvate to benzaldehyde and phenethanol has been reported [70]. Flavour compounds originating from Phe which have been identified in cheese $[2,34]$ or in model systems [64] include phenylmethanol, phenylethanol, phenylpropanone, methylphenyl hydroxyacetate, phenylacetaldehyde, phenylpyruvate and phenylethyl acetate. Phenylethanol may be produced in Camembert and other mould- or smear-ripened cheese as a result of transamination, decarboxylation or reduction reactions by yeasts growing on their surface $[2,34]$. In Cheddar (and other varieties made using only a primary starter), phenylethanol and phenylacetaldehyde can be produced by Strecker degradation of phenylalanine [34]; high concentrations of phenylacetaldehyde contribute to astringent, bitter and stinging flavour sensations. Catabolism of Tyr (Fig. 13c) results in the formation of $p$-hydroxy-phenylpyruvate. Tyr serves as precursor for 3 compounds in cheese: tyramine formed by decarboxylation, and $p$-cresol and phenol formed by atypical Strecker degradation [36]. Nonstarter lactobacilli in Gouda and Vacherin du Haut-Doubs (also known as Mont d'Or) cheeses are thought to be responsible for producing $p$-cresol [32], whereas phenol has been found in high concentrations in Limburger cheese [111]. A major concern to the dairy industry is the occurrence of offflavours. Compounds like $p$-cresol, phenethanol, phenylacetaldehyde and indole have been associated with these unclean flavours, which are believed to be formed via catabolism of aromatic amino acids.

Tyramine is a biogenic amine that is frequently detected in cheese [144], and is the most common cause of monoamine intoxication. Monoamine intoxication is characterized by an increase in blood pressure, resulting in palpitations, severe headaches, hypertension, nausea and vomiting, and has been associated with the consumption of cheese [87]. 


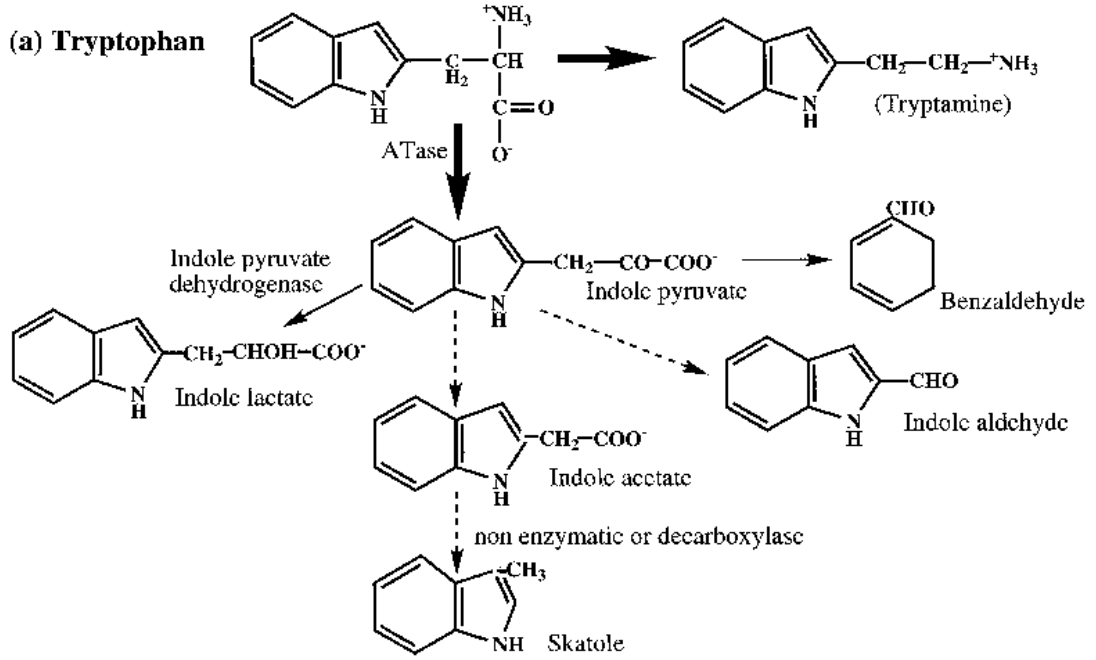

(b) Phenylalanine
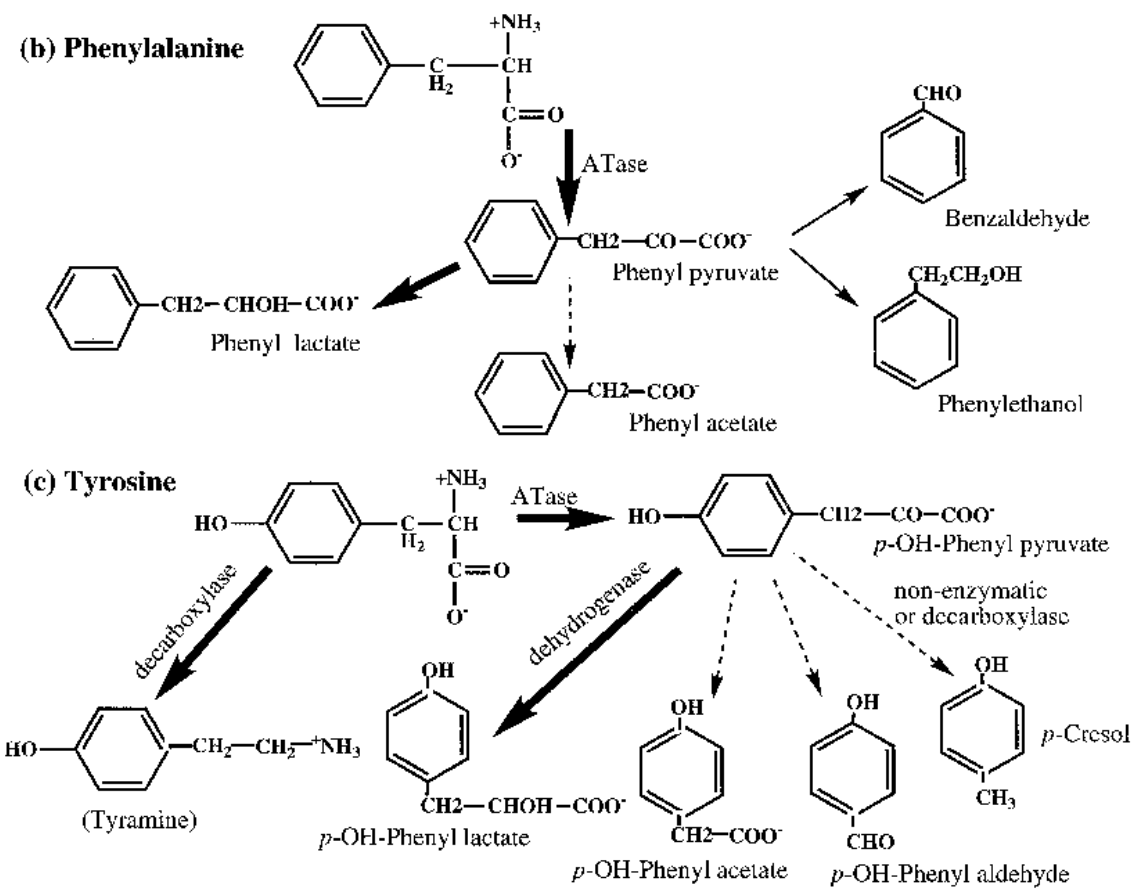

Figure 13. Pathways for the catabolism of tryptophan (a), phenylalanine (b) and tyrosine (c), by starter, adjunct and non-starter bacteria (modified from [24]). Thick arrows: enzymatic reactions; thin arrows: non-enzymatic chemical reactions; dashed arrows: unknown mechanism; and Atase: aminotransferase.

Figure 13. Catabolisme du tryptophane (a), de la phénylalanine (b) et de la tyrosine (c), par les levains acidifiants, les levains additionnels et les bactéries non-levains (d'après [24]). Flèches en gras : réaction enzymatiques; flèches non en gras : réactions chimiques non enzymatiques; flèches en pointillés : mécanisme inconnu ; Atase : aminotransférase. 
2.6. Catabolism of arginine, aspartate, glutamate, and threonine

A common pathway in LAB for the catabolism of Arg results in the conversion of $1 \mathrm{~mol}$ of Arg into $2 \mathrm{~mol}$ of ammonia and 1 mol each of ornithine, carbon dioxide, and ATP [24]. Three different Asp catabolic pathways have been reported [24]; however, the details and distribution of these pathways are still not well understood. The reported pathways of Glu catabolism produce $\alpha$-ketoglutarate by the action of an aminotransferase or dehydrogenase, or $\gamma$-aminobutyrate (GABA) by the action of a decarboxylase [24]. GABA production is known to occur in cheese, and Zoon and Allersma [154] have reported a correlation between the production of $\mathrm{CO}_{2}$ and GABA in cheese with an increasing number of eyes. However, to our knowledge there are no reports suggesting that GABA has a direct or indirect impact on cheese flavour. Thr catabolism converts Thr to acetaldehyde and Gly [86]; acetaldehyde is the flavour compound typical of yogurt flavour [134].

\subsection{Catabolism of branched-chain amino acids}

Catabolism of branched-chain amino acids is most likely initiated in L. lactis by an aminotransferase, converting Leu, Ile, and Val to $\alpha$-ketoisocaproate, $\alpha$-keto- $\beta$-methylvalerate and $\alpha$-ketoisovalerate, respectively. Catabolism of branched-chain amino acids is typically associated with the generation of compounds having a detrimental effect on product aroma or flavour in the production of fermented dairy products [24]. The aldehyde and alcohol products from catabolism of branched-chain amino acids are known to cause defects in cheese. Cheeses containing 18-90 ppm 3-methylbutanal and 9-45 ppm 3-methylbutanol, also produced by the catabolism of branched-chain amino acids, were graded lower for flavour quality and were maltier than the control cheeses
[18]. Additionally, flavours described as harsh and dull were correlated with elevated concentrations of 3-methylbutanal and 2-methylpropanal [34]. In Emmental, 3-methylbutanal can be present at high levels, and it has been reported that even if it is not one of the compounds defining typical flavour or odour, it may play a role in suppressing the unpleasant, sweaty odour of butyric acid [113].

\section{CONCLUSIONS}

The general pathways for the formation of volatile and non-volatile compounds are now well characterized for most cheese varieties, and detailed knowledge is available on the production of the primary products of lipolysis (FFA), glycolysis (lactate and products of citrate metabolism) and proteolysis (FAA) in certain varieties (e.g., Gouda and Cheddar). However, much work remains to be done in order to understand the mechanisms by which these primary products are converted to volatile flavour compounds. Much is now known of the enzyme systems involved in the conversion of caseins to FAA, but it is only recently that attention has been paid to the enzymes of starters involved in amino-acid catabolism. Much research remains to be done in this area, with the potential for selection or genetic manipulation of starters with improved cheesemaking properties.

\section{ACKNOWLEDGEMENT}

The authors would like to thank Professor T.M. Cogan for useful comments on the manuscript.

\section{REFERENCES}

[1] Adda J., Dumont J.P., Les substances responsables de l'arôme des fromages à pâte molle, Lait 54 (1974) 1-74.

[2] Adda J., Gripon J.C., Vassal L., The chemistry of flavour and texture generation in cheese, Food Chem. 9 (1982) 115-129. 
[3] Adda J., Czulak J., Mocquot G., Vassal L., in: Cross H.R., Overby A.J. (Eds.), Cheese, Mea Science, Milk Science and Technology, Elsevier Sci. Publ., Amsterdam, The Netherlands, 1988, pp. 373-392.

[4] Ardo Y., Petterson H.E., Accelerated cheese ripening with heat-treated cells of Lactobacillus helveticus and a commercial proteolytic enzyme, J. Dairy Res. 55 (1988) 239-245.

[5] Aston J.W., Dulley J.R., Cheddar cheese flavour, Aust. J. Dairy Technol. 37 (1982) 59-64.

[6] Aston J.W., Douglas K., The production of volatile sulphur compounds in Cheddar cheeses during accelerated ripening, Aust. J. Dairy Technol. 38 (1983) 66-70.

[7] Aston J.W., Greive P.A., Durward I.G., Dulle, J.R., Proteolysis and flavour development in Cheddar cheese, Aust. J. Dairy Technol. 38 (1983) 59-65.

[8] Banks J., Muir D.D., Brechany E.Y., Law A.J.R., The production of low fat cheese, Proc. 3rd Cheese Symp., Moorepark, Fermoy, Co. Cork, Ireland, 1992, pp. 67-80.

[9] Bastian E.D., Brown R.J., Plasmin in milk and dairy products: an update, Int. Dairy J. 6 (1996) 435-457.

[10] Barbeiri G., Bolzoni L., Careri M., Mangia A. Parolari G., Spagnoli S., Virgili R., Study of the volatile fraction of Parmesan cheese, J. Agric. Food Chem. 42 (1994) 1170-1176.

[11] Barlow I., Lloyd G.T., Ramshaw E.H., Miller A.J., McCabe G.P., McCabe L., Correlations and changes in flavour and chemical parameters of Cheddar cheeses during maturation, Aust. J. Dairy Technol. 44 (1989) 7-18.

[12] Bills D.D., Day E.A., Determination of the major free fatty acids of Cheddar cheese, J. Dairy Sci. 47 (1964) 733-738.

[13] Bhownik T., Marth E.H., Esterases of Micrococcus and Pediococcus species in cheese ripening: a review, J. Dairy Sci. 73 (1990) 879-886.

[14] Bosset J.O., Liardon R., The aroma composition of Swiss Gruyère. III. Relative changes in the content of alkaline and neutral components during ripening, Lebensm. Wiss. u. Technol. 18 (1985) 178-185.

[15] Bosset J.O., Gauch R., Comparison of the volatile flavour compounds of six European 'AOC' cheeses by using a new dynamic headspace GC-MS method, Int. Dairy J. 3 (1993) 359-377.

[16] Bosset J.O., Gauch R., Mariaca R., Klein B., Comparison of various sample treatments for the analysis of volatile compounds by GC-MS application to the Swiss Emmental cheese, Mitt Geb. Lebensm. Hyg. 86 (1995) 672-698.

[17] Bosset J.O., Butikofer U., Gauch R., Sieber R. Ripening of Emmental cheese wrapped in foil with and without addition of Lactobacillus case subsp. casei. II. Gas chromatographic investi- gation of some volatile neutral compounds using dynamic headspace, Lebensm. Wiss. u. Technol. 30 (1997) 464-470.

[18] Braun S.D., Olson N.F., Microencapsulation of cell-free extracts to demonstrate the feasibility of heterogeneous enzyme systems and cofactor recycling for the development of flavour in cheese, J. Dairy Sci. 69 (1986) 1202-1208.

[19] Broome M.C., Krause D.A., Hickey M.W., The use of non-starter lactobacilli in Cheddar cheese manufacture, Aust. J. Dairy Technol. 45 (1990) 67-73.

[20] Casey J., Dobb R., Microbial routes to aromatic aldehydes, Enzyme Microbiol. Technol. 14 (1992) 739-747.

[21] Charlier P., Crouzet J., Production of lactones by Penicillium roqueforti, Biotechnol. Lett. 14 (1992) 275-280.

[22] Chick J.F., Marchesseau K., Gripon J.C., Intracellular esterase from Lactococccus lactis subsp. lactis NCDO 763: purification and characterization, Int. Dairy J. 7 (1997) 169-174

[23] Christensen J.E., Johnson M.E., Steel J.L., Production of Cheddar cheese using Lactococcus lactis ssp. cremoris SK11 derivative with enhanced aminopeptidase activity, Int. Dairy J. 5 (1995) 367-379.

[24] Christensen J.E., Dudley, E.G., Pederson, J.A., Steele J.L., Peptidases and amino acid catabolism in lactic acid bacteria, Antonie Leeuwenhoek 76 (1999) 217-246.

[25] Cogan T.M., The Leuconostocs: milk products, in: Gilliland S.E. (Ed.), Bacterial Starter Cultures for Foods, CRC Press, Boca Raton, FL, 1985, pp. 25-40.

[26] Cogan T.M., Hill C., Cheese starter cultures, in Fox P.F. (Ed.), Cheese: Chemistry, Physics and Microbiology, Chapman \& Hall, London, 2nd ed., 1993, pp. 193-255.

[27] Considine T., Healy A., Kelly A.L., McSweeney P.L.H., Proteolytic specificity of elastase on bovine $\beta$-casein, Food Chem. 66 (1999) 463-470.

[28] Cousins C.M., Sharpe M.E., Law B.A., The bacteriological quality of milk for Cheddar cheesemaking, Dairy Ind. Int. 42 (1977) 12-13.

[29] Creamer L.K., Lawrence R.C., Gilles J., Effect of acidification of cheese milk on the resultant Cheddar cheese, N.Z. J. Dairy Sci. Technol. 20 (1985) 185-203.

[30] Dimos A., Urbach G.E., Miller A.J., Changes in flavour and volatiles of full-fat and low-fat cheeses during maturation, Int. Dairy J. 6 (1996) 981-995.

[31] Dufossé L., Latrasse A., Spinnler H.E., Importance des lactones dans les arômes alimentaires structures, distribution, propriétés sensorielles et biosynthèse, Sci. Aliment. 14 (1994) 17-21.

[32] Dumont J.P., Roger S., Cerf P., Adda J., Étude de composés volatils neutres présents dans le Vacherin, Lait 54 (1974) 501-516. 
[33] Dumont J.P., Roger S., Adda J., Camembert aroma: identification of minor constituents, Lait 56 (1976) 595-599.

[34] Dunn H.C., Lindsay R.C., Evaluation of the role of microbial Strecker-derived aroma compounds in unclean-type flavours of Cheddar cheese, J. Dairy Sci. 68 (1985) 2859-2874.

[35] Eigel W.N., Butler J.E., Ernstrom C.A., Farrell H.M. Jr., Harwalkar V.R., Jenness R., Whitney R.McL., Nomenclature of proteins of cow's milk: fifth revision, J. Dairy Sci. 67 (1984) 1599-1631.

[36] Elsden S.R., Hilton M.G., Waller J.M., The end products of the metabolism of aromatic amino acids by Clostridia, Arch. Microbiol. 107 (1976) 283-288.

[37] El-Soda M., El-Wahab H.A., Ezzat N. Desmazeaud M.J., Ismail A., The esterolytic and lipolytic activities of the lactobacilli. II Detection of esterase system of Lactobacillus helveticus, Lactobacillus bulgaricus, Lactobacillus lactis and Lactobacillus acidophilus, Lait 66 (1986) 431-443.

[38] Eriksen S., Flavour of milk and milk products 1. The role of lactones, Milchwissenschaft 31 (1975) 549-552.

[39] Farkye N.Y., Fox P.F., Contribution of plasmin to Cheddar cheese ripening: effect of added plasmin, J. Dairy Res. 59 (1992) 209-216.

[40] Ferchichi M., Hemme D., Boullianne C., Influence of oxygen and $\mathrm{pH}$ on methanethiol production from L-methionine by Brevibacterium linens CNRZ 918, Appl. Environ. Microbiol. 51 (1986) 725-729.

[41] Ferchichi M., Hemme D., Nardi M., Induction of methanethiol production by Brevibacterium linens CNRZ 918, J. Gen. Microbiol. 132 (1986) 3075-3082.

[42] Foissy H., Examination of Brevibacterium linens by an electrophoretic zymogram technique, J. Gen. Microbiol. 80 (1974) 197-207.

[43] Foda F.A., Hammond E.G., Reinbold G.W., Hotchkiss, D.K., Role of fat in flavor of Cheddar cheese, J. Dairy Sci. 57 (1974) 1137-1142.

[44] Folkertsma B., Fox P.F., McSweeney P.L.H., Acceleration of Cheddar cheese ripening at elevated temperatures, Int. Dairy J. 6 (1996) 1117-1134.

[45] Fox P.F., Acceleration of cheese ripening, Food Biotechnol. 2 (1988/89) 133-185.

[46] Fox P.F., Proteolysis during cheese manufacture and ripening, J. Dairy Sci. 72 (1989) 1379-1400.

[47] Fox P.F, Law J., Enzymology of cheese ripening, Food Biotechnol. 5 (1991) 239-262.

[48] Fox P.F., Stepaniak L., Enzymes in cheese technology, Int. Dairy J. 3 (1993) 509-530.

[49] Fox P.F., McSweeney P.L.H., Proteolysis in cheese during ripening, Food Rev. Int. 12 (4) (1996) 457-509.
[50] Fox P.F., Wallace J.M., Formation of flavour compounds, Adv. Appl. Microbiol. 45 (1997) 17-85.

[51] Fox P.F., Lucey J.A., Cogan T.M., Glycolysis and related reactions during cheese manufacture and ripening, Crit. Rev. Food Sci. Nutr. 29 (1990) 237-253.

[52] Fox P.F., McSweeney P.L.H., Singh T.K., Methods for assessing proteolysis in cheese during ripening, in: Malin E.L., Tunick M.H. (Eds.), Chemistry of Structure/Function Relationships in Cheese, Plenum Press, New York, pp. 161-194.

[53] Fox P.F., Singh T.K., McSweeney P.L H., Biogenesis of flavour compounds in cheese, in: Malin E.L., Tunick M.H. (Eds.), Chemistry of Structure/Function Relationships in Cheese, Plenum Press, New York, pp. 59-98.

[54] Gao S., Oh D.H., Broadbent J.R., Johnson M.E., Weimer B.C., Steele J.L., Aromatic amino acid catabolism by lactococci, Lait 77 (1997) 371-381.

[55] Grappin R., Rank T., Olson N., Primary proteolysis of cheese proteins during ripening, $\mathrm{A}$ review, J. Dairy Sci. 68 (1985) 531-540.

[56] Gripon J.C. Mould-ripened cheeses, in: Fox P.F (Ed.), Cheese: Chemistry, Physics and Microbiology, Chapman and Hall, London, UK, Vol. 2, 1993, pp. 111-136.

[57] Gripon J.C., Monnet V., Lamberet G., Desmazeaud M.J., Microbial enzymes in cheese ripening, in: Fox P.F. (Ed.), Food Enzymes, Elsevier Appl. Sci., London, 1991, pp. 131-168.

[58] Grufferty M.B., Fox P.F., Milk alkaline proteinase: a review, J. Dairy Res. 55 (1988) 609-630.

[59] Hemme D., Bouillane C., Metro F., Desmazeaud M.J., Microbial catabolism of amino acids during cheese ripening, Sci. Aliment. 2 (1982) 113-123.

[60] Holland R., Coolbear T., Purification of tributyrin esterase from Lactococcus lactis subsp. lactis E8, J. Dairy Res. 63 (1996) 131-140.

[61] Hugenholtz J., Citrate metabolism in lactic acid bacteria, FEMS Microbiol. Rev. 12 (1993) 165-168.

[62] Hummel W.W., Kula M.R. Isolation and characterization of a bacterium possessing L-phenylalanine dehydrogenase activity, Arch. Microbiol. 137 (1984) 47-52.

[63] Imhof R., Bosset J.O., Relationship between microorganisms and formation of aroma compounds in fermented dairy products (review) Z. Lebensm. Unters. Forsch. 198 (1994) 267-276

[64] Jollivet N., Bezenger M.C., Vayssier Y., Belin J.M., Production of volatile compounds in model milk and cheese media by eight strains of Geotrichum candidum Link, J. Dairy Res. 61 (1992) 241-248. 
[65] Joosten H.M.L.J., Stadhouders J., Conditions allowing the formation of biogenic amines in cheese. 1: Decarboxylase properties of starter bacteria, Neth. Milk Dairy J. 41 (1987) 247-258.

[66] Kaminogawa S., Yamauchi K., Miyazawa S., Koga Y., Degradation of casein components by acid protease of bovine milk, J. Dairy Sci. 63 (1980) 701-704.

[67] Karahadian C., Lindsay R.C., Integrated roles of lactate, ammonia, and calcium in texture development of mold surface-ripening cheese, J. Dairy Sci. 70 (1987) 909-918.

[68] Khalid N.M., Marth E.H., Lactobacilli - their enzymes and role in ripening and spoilage of cheese: a review, J. Dairy Sci. 73 (1990) 2669-2684.

[69] Kim J.C., Olson N.F., Production of methanethio in milk-fat coated microcapsules containing Brevibacterium linens and methionine, J. Dairy Res. 56 (1989) 799-811.

[70] Kong Y., Strickland M., Broadbent J.R., Tyrosine and phenylalanine catabolism by Lactobacillus casei flavour adjuncts: biochemistry and implications in cheese flavour, J. Dairy Sci. 79 (Suppl. 1) (1996) 101

[71] Kosikowski F.V., Mocquot G., Advances in Cheese Technology, FAO Agric. Studies 38 (1958).

[72] Kungi E.R.S., Micrav I., Hagting A., Poolman B., Konings W.N., The proteolytic system of lactic acid bacteria, Antonie Leeuwenhoek Int. J. Gen. M. 70 (1996) 187-221.

[73] Law J., Haandrikman A., Proteolytic enzymes of lactic acid bacteria, Int. Dairy J. 7 (1997) 1-11.

[74] Law B.A., Castanon M.J., Sharpe M.E., Effect of non-starter bacteria on the chemical composition and flavour of Cheddar cheese, J. Dairy Res. 43 (1976) 117-125.

[75] Le Bars D., Gripon J.C., Specificity of plasmin towards bovine $\alpha_{\text {s2 }}$-casein, J. Dairy Res. 56 (1989) 817-821.

[76] Le Bars D., Gripon J.C., Hydrolysis of $\alpha_{\mathrm{s1}}$-casein by bovine plasmin, Lait 73 (1993) 337-344.

[77] Lawrence R.C., Creamer L.K., Gilles J., Martley F.G., Cheddar cheese flavour. I. The role of starters and rennets, N.Z. J. Dairy Sci Technol. 7 (1972) 32-37.

[78] Lawrence R.C., Gilles J., Creamer L.K., The relationship between cheese texture and flavour, N.Z. J. Dairy Sci. Technol. 18 (1983) 175-190.

[79] Lemieux L., Simard R.E., Bitter flavour in dairy products. I. A review of the factors likely to influence its development, mainly in cheese manufacture, Lait 71 (1991) 599-636.

[80] Lemieux L., Simard R.E., Bitter flavour in dairy products. II. A review of bitter peptides from caseins: their formation, isolation and identification, structure masking and inhibition, Lait 72 (1992) 335-382.
[81] Lenoir J., The surface flora and its role in the ripening of cheese, Int. Dairy Fed. Bull. 171 (1984) 3-20.

[82] Liardon R., Bosset J.O., Blanc B., The aroma composition of Swiss Gruyère cheese. I. The alkaline volatile components, Lebensm. Wiss. u. Technol. 15 (1982) 143-147.

[83] Lynch C.M., McSweeney P.L.H., Fox P.F., Cogan T.M., Drinan F.D., Contribution of starter and non-starter lactobacilli to proteolysis in Cheddar cheese with controlled microflora, Lait 77 (1997) 441-459.

[84] Manning D.J., Chemical production of essential flavour compounds, J. Dairy Res. 46 (1979) 531-537.

[85] Manning D.J., Cheddar cheese flavour studies II: Relative flavour contributions of individual volatile components, J. Dairy Res. 46 (1979) 523-529.

[86] Marshall J.D., Cole W.M., Threonine aldolase and alcohol dehydrogenase activities in Lacto bacillus bulgaricus and Lactobacillus acidophilus and their contribution to flavour production in fermented milks, J. Dairy Res. 50 (1983) 375-379.

[87] McCabe B.J., Dietary tyramine and other pressor amines in MAOI regimens: a review. Jamer. Diet. Assoc., 86 (1986) 1059-1064.

[88] McGarry A., Law J., Coffey A., Daly C., Fox P.F., Fitzgerald G.F., Effect of genetically modifying the lactococcal proteolytic system in ripening and flavour development in Cheddar cheese, Appl. Environ. Microbiol. 60 (1994) 4226-4223.

[89] McSweeney P.L.H., Fox P. F., Indices of Cheddar cheese ripening, Proc. 5th Cheese Symp. Moorepark, Fermoy, Co. Cork, Ireland, 1997 pp. 73-89.

[90] McSweeney P.L.H., Olson N.F., Fox P.F., Healy A., Hojrup P. Proteolytic specificity of plasmin on bovine $\alpha_{\mathrm{s} 1}$-casein, Food Biotechnol. 7 (1993) 143-158.

[91] McSweeney P.L.H., Walsh E.M., Fox P.F., Cogan T.M., Drinan F.D., Castelo-Gonzalez M., A procedure for the manufacture of Cheddar cheese under controlled bacteriological conditions and the effect of adjunct lactobacilli on cheese quality, Ir. J. Agric. Food Res. 33 (1994) 183-192.

[92] McSweeney P.L.H., Fox P.F., Olson N.F., Proteolysis of bovine caseins by cathepsin D: preliminary observations and comparison with chymosin, Int. Dairy J. 5 (1995) 321-336.

[93] McSweeney P.L.H., Nursten H.E., Urbach G., Flavours and off-flavours in milk and dairy products, in: Fox P.F. (Ed.), Advanced Dairy Chemistry, Chapman and Hall, London, UK, 2nd ed. vol. 3, 1997, pp. 403-468.

[94] Meinhart E., Schreier P., Study of flavour compounds from Parmagiano Reggiano cheese, Milchwissenschaft 41 (1986) 689-691. 
[95] Molimard P., Spinnler H.E., Review: compounds involved in the flavour of surface moldripened cheeses: origins and properties, J. Dairy Sci. 79 (1996) 169-184.

[96] Molimard P., Le-Quere J.L., Spinnler H.E., Les lipides et la flaveur des produits laitiers, Oléagin. Corps Gras Lipides 4 (1997) 301-311.

[97] Mulder H., Taste and flavour-forming substances in cheese, Neth. Milk Dairy J. 6 (1952) 157-167.

[98] Muller C.J., Kepner R.E., Webb A.D., Identification of 3-(methylthio)-propanol as an aroma constituent in Cabernet Sauvignon and Ruby Cabernet wines, Am. J. Enol. Vitic. 22 (1971) 953.

[99] Nelson J.H., Jensen R.G., Pitas R.E., Pregastric esterase and other oral lipases - a review, J. Dairy Sci. 60 (1977) 327-362.

[100] Ney K.H., Technik der Aromauntersuchung, Gordian 73 (1973) 380-387.

[101] Ney K.H., Recent advances in cheese flavour research, in: Charalambous G., Inglett G. (Eds.), The Quality of Foods and Beverages. Chemistry and Technology, vol. 1, Academic Press, New York, 1981, pp. 385-435.

[102] Ney K.H., Wirotama I.P.G., Unsubstituted aliphatic monocarboxilic acids, alpha-keto-acids, and amines in Cheddar cheese aroma, Z Lebensm. Unters. Forsch. 146 (1971) 337-343.

[103] Ney K.H., Wirotama I.P.G., Investigation of the aroma of Edelpizkäse, a German blue cheese, Z. Lebensm. Unters. Forsch. 149 (1972) 275-279.

[104] Ney K.H., Wirotama I.P.G., Unsubstituted aliphatic monocarboxylic acids, alpha-keto-acids in Camembert, Z. Lebensm. Unters. Forsch. 152 (1973) 32-34

[105] Ney K.H., Wirotama I.P.G., Investigation of the aroma constituents of Fontina - an Italian cheese, Fette Seifen Anstrichm. 80 (1978) 249-251.

[106] Noomen A., The role of the surface flora in the softening of cheeses with a low initial $\mathrm{pH}$, Neth. Milk Dairy J. 37 (1983) 229-232.

[107] Ohren J.A., Tuckey S.L., Relation of flavor development in Cheddar cheese to chemical changes in the fat of the cheese, J. Dairy Sci. 52 (1967) 598-607.

[108] Olivecrona T., Vilaró S., Bengtsson-Olivecrona G., Indigenous enzymes in milk. II. Lipases in milk, in: Fox P.F. (Ed.), Advanced Dairy Chemistry. 1. Proteins, Elsevier Appl. Sci., London, 1992, pp. 292-310.

[109] Olson N.F., The impact of lactic acid bacteria on cheese flavor, FEMS Microbiol. Rev. 87 (1990) 131-147.

[110] Paquet J., Gripon J.C., Intracellular peptide hydrolases of Penicillium roqueforti, Milchwissenschaft 35 (1980) 72-74.

[111] Parliment T.H., Kolor M.G., Rizzo D.J., Volatile components of Limburger cheese, J. Agric. Food Chem. 30 (1982) 1006-1008.
[112] Polo C., Ramos M., Sanchez R., Free amino acids by high performance liquid chromatography and peptides by gel electrophoresis in Mahon cheese during ripening, Food Chem. 16 (1985) 85-96.

[113] Preininger M., Warmke R., Grosch W., Identification of the character impact flavour compounds of Swiss cheese by sensory studies of models, Z. Lebensm. Unters. Forsch. 202 (1996) 30-34.

[114] Puchades R. Lemieux L., Simard R.E., Evolution of free amino acids during ripening of Cheddar cheese containing added lactobacilli strains, J. Food Sci. 54 (1989) 885-888, 946.

[115] Rank T.C., Grappin R., Olson N.F., Secondary proteolysis of cheese during ripening: a review, J. Dairy Sci. 68 (1985) 801-805.

[116] Rattray F.P., Fox P.F., Purification and characterization of an intracellular esterase from $\mathrm{Bre}$ vibacterium linens ATCC 9174, Int. Dairy J. 7 (1997) 273-278.

[117] Rattray F.P., Fox P.F., Purification and characterization of an intracellular aminopeptidase from Brevibacterium linens ATCC 9174, Lait 77 (1997) 169-180.

[118] Rattray F.P., Fox P.F., Healy A., Specificity of an extracellular proteinase from Brevibacterium linens ATCC 9174 on bovine $\alpha_{\mathrm{s1}}$-casein, Appl. Environ. Microbiol. 62 (1996) 501-506.

[119] Rattray F.P., Fox P.F., Healy A., Specificity of an extracellular proteinase from Brevibacterium linens ATCC 9174 on bovine $\beta$-casein, Appl. Environ. Microbiol. 63 (1997) 2468-2471.

[120] Reps A., Bacterial surface-ripened cheeses, in: Fox P.F. (Ed.), Cheese: Chemistry, Physics and Microbiology, 2nd ed., vol. 2, Chapman \& Hall, London, 1993, pp. 137-172.

[121] Rothe G.A.L., Harboe M.K., Mactiny S.C., Quantification of milk-clotting enzymes in 40 commercial bovine rennets, comparing rocket immunoelectrophoresis with an activity ratio assay, J. Dairy Res. 44 (1977) 73-77.

[122] Rychlik M., Warmke R., Grosch W., Ripening of Emmental cheese wrapped in foil with and without addition of Lactobacillus casei subp. casei. III. Analysis of characterer impact flavour compounds, Lebensm. Wiss. u. Technol. 30 (1997) 471-478.

[123] Santos M.H., Biogenic amines: their importance in foods, Int. J. Food Microbiol. 29 (1991) 213-231.

[124] Sieber R., Lavanchy P., Biogenic amines in dairy products and cheese, Mitt. Geb. Lebensm. Hyg. 81 (1990) 82-105.

[125] Sieber R., Butikofer U., Bosset J.O., Benzoic acid as a natural compound in cultured dairy products and cheese, Int. Dairy J. 5 (1995) 227-246.

[126] Sloot D., Hofman H.J., Alkylpyrazines in Emmental cheese, J. Agric. Food Chem. 23 (1975) 358 
[127] Smith T.A., Amines in food, Food Chem. 6 (1981) 169-200.

[128] Sørhaug T., Ordal Z.J., Cell-bound lipase and esterase of Brevibacterium linens, Appl. Microbiol. 25 (1974) 607-608.

[129] Steele J.L., Ünlü G., Impact of lactic acid bacteria on cheese flavor development, Food Technol. 46 (1992) 128-130.

[130] Steffen C., Konzentration und Konfiguration des milchsäre im reifenden Emmentalerkäse, Diss. 4630, Eidy Tech. Hochschule, Zurich, 1971.

[131] Steffen C., Glättli H., Steiger G., Flückiger E., Bühlmann C., Lavanchy P., Nick B., Vergleichende Untersuchungen von Greyerzerkäsen mit und ohne Nachgärung. I Bakteriologische, biochemische, chemische und rheologische Untersuchungen, Schweiz. Milchwirtsch. Forsch. 9 (1980) 19-27.

[132] Steffen C., Flückiger E., Bosset J.O., Rüegg M. Swiss-type varieties, in: Fox P.F. (Ed.), Cheese Chemistry, Physics and microbiology. Majo Cheese Groups, Vol. 2, Elsevier Appl. Sci., London and New York, 1987, pp. 93-120.

[133] Suter B., Grob K., Pacciarelli B., Determination of fat content and fatty acid composition through 1-min transesterification in the food sample: principles, Z. Lebensm. Unters. Forsch. (1997) 204, 252.

[134] Tamine A.Y., Deeth H.C., Yogurt, technology and biochemistry, J. Food Protect. 43 (1980) 939.

[135] Taylor S.L., Keefe T.J., Windham E.S., Howell J.F., Outbreak of histamine poisoning associated with consumption of Swiss cheese, J. Food Protect. 45 (1982) 455-457.

[136] Thomas T.D., Crow V.L., Mechanism of D(-) lactic acid formation in Cheddar cheese, N.Z J. Dairy Sci. Technol. 18 (1983) 131-141.

[137] Turner K.W., Morris H.A., Martley F.G., Swisstype cheese. II. The role of thermophilic lactobacilli in sugar fermentation, N.Z. J. Dairy Sci. Technol. 18 (1983) 117-124.

[138] Urbach G., Relations between cheese flavou and chemical composition, Int. Dairy J. 3 (1993) 389-422.

[139] Urbach G., Contribution of lactic acid bacteria to flavour compound formation in dairy products, Int. Dairy J. 5 (1995) 877-903.

[140] Vedamuthu E.R., The dairy Leuconostoc: use in dairy products, J. Dairy Sci. 77 (1994) 2725-2737.

[141] Verdi R.J., Barbano D.M., Effects of coagulants, somatic cell enzymes and extracellula bacterial enzymes on plasminogen activation, J. Dairy Sci. 74 (1991) 772-782.
[142] Visser F.M.W., de GrootMostert A.E.A., Contribution of enzymes from rennet, starter bac teria and milk to proteolysis and flavour development in Gouda cheese. 4. Protein breakdown: a gel electrophoretic study, N.Z. J. Milk Dairy J. 31 (1977) 247-264.

[143] Visser S., Slangen K.J., Alting A.C., Vreeman H.J. Specificity of bovine plasmin in its action on bovine $\alpha$-casein, Milchwissenschaft 44 (1989) $335-339$.

[144] Voight M.N., Eitenmiller R.R., Role of histidine and tyrosine decarboxylases and monoand diamine oxidases in amine building-up in cheese, J. Food Protect. 41 (1978) 182-186

[145] Weinstein M.J., Doolittle R.F., Differential specificities of thrombin, plasmin and trypsin with regard to synthetic and natural substrates and inhibitors, Biochim. Biophys. Acta 258 (1972) 577-590.

[146] Wijesundera C., Urbach G., Flavour of Cheddar cheese. Final Report to the Dairy Research and Development Corporation. PO Box 8000 Glen Iris 3146, Victoria, Australia, 1993, p. 31.

[147] Wijesundera C., Drury L., Muthuku-marappan K., Gunasekaran S., Everett D.W., Flavour developmenet and distribution of fat globule size and shape in Cheddar-type cheeses made from skim milk homogenised with AMF or its fractions, Aust. J. Dairy Technol. 53 (1998) 107.

[148] Wilkinson M., Studies on the acceleration of Cheddar cheese ripening, Ph.D. thesis, Nat. Univ. Ireland, Cork, 1992.

[149] Wong N.P., Ellis R., La Croix D.E., Quantitative determination of lactones in Cheddar cheese, J. Dairy Sci. 58 (1975) 1437-1441.

[150] Woo A.H., Lindsay R.C., Concentration of major free fatty acids and flavor development in Italian cheese varieties, J. Dairy Sci. 67 (1984) 960-968.

[151] Woo A.H., Kollege S., Lindsay R.C., Quantification of major free fatty acids in several cheese varieties, J. Dairy Sci. 67 (1984) 874-878.

[152] Wood A.F., The determination of volatile compounds in cheese, M. Appl. Sci. thesis, Queensland Univ. Technol., Brisbane, Australia, 1989.

[153] Yvon M., Thirouin S., Rijnen L., Fromentier D., Gripon J.C., An aminotransferase from $\mathrm{Lac}$ tococcus lactis initiates conversion of amino acids to cheese flavour compounds, Appl. Environ. Microbiol. 63 (1997) 414-419.

[154] Zoon P., Allersma D., Eye and crack formation in cheese by carbon dioxide from decarboxylation of glutamic acid. Neth. Milk Dairy J. 50 (1996) 309-318. 